\title{
Development of a conceptual model of the hydrologic response of tropical Andean micro-catchments in Southern Ecuador
}

P. Crespo ${ }^{1,2,3}$, J. Feyen ${ }^{1}$, W. Buytaert ${ }^{4}$, R. Célleri $^{1}$, H.-G. Frede ${ }^{2}$, M. Ramírez ${ }^{3}$, and L. Breuer ${ }^{2}$

${ }^{1}$ Grupo de Ciencias de la Tierra y del Ambiente, DIUC, Universidad de Cuenca, Quinta Balzaín, Av. Victor Manuel Albornoz, Cuenca, Ecuador

${ }^{2}$ Institute for Landscape Ecology and Resources Management, Research Centre for BioSystems, Land Use and Nutrition (IFZ), Justus-Liebig Universität of Gießen, Heinrich-Buff Ring 26, 35392 Giessen, Germany

${ }^{3}$ PROMAS, Universidad de Cuenca, Av. 12 de Abril s/n Ciudadela Universitaria, Cuenca, Ecuador

${ }^{4}$ Civil and Environmental Engineering, Imperial College London, Skempton Building, SW7 2AZ, London, UK

Received: 6 February 2012 - Accepted: 9 February 2012 - Published: 24 February 2012 Correspondence to: P. Crespo (patricio.crespo@ucuenca.edu.ec) Published by Copernicus Publications on behalf of the European Geosciences Union.

Hydrologic response of tropical Andean micro-catchments in Southern Ecuador

P. Crespo et al.

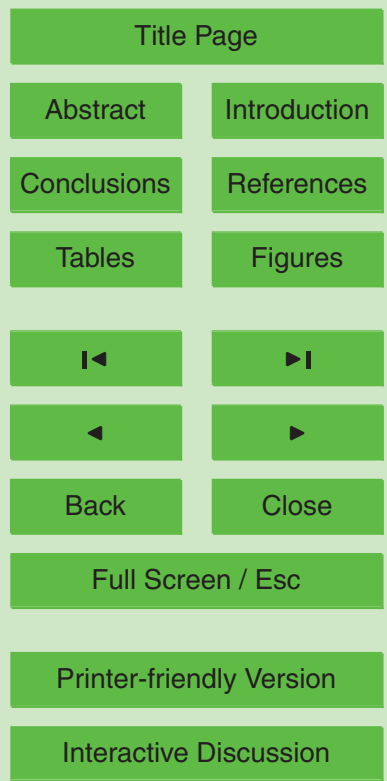




\section{Abstract}

This paper presents a lumped conceptual model designed for simulating the rainfallrunoff response of mountain micro-catchments with natural vegetation located in the south of Ecuador. The conceptual model is mimicking the soil hydrology and consists

5 of a maximum of three linear reservoirs in series. A two and three reservoir model structure were tested, respectively A GLUE uncertainty analysis was applied to assess the model performance. Simulation results of the discharge confirmed the applicability of the soil-based conceptual model structure for the selected study areas, during model calibration and validation. The three reservoir model best predicted the runoff, nevercatchments with páramo vegetation. Although differences in climate regime, vegetation, and soil of the selected catchments runoff is strongly controlled by the precipitation and soil type, and the horizons contributing to runoff are defined by their antecedent wetness. Results confirm that the discharge is mainly controlled by lateral subsurface flow through the organic horizons, while during dry conditions the C-horizon and the bedrock mainly contribute to discharge. Lateral transport through the densely rooted top horizon and the litter layer occurs during storm events, being under those conditions the major discharge component. Overland flow is a local phenomenon, negligible in comparison to the other flow components.

\section{Introduction}

Mountain ecosystems sustain freshwater resources, human livelihoods and well-being, in particular of Southern America and Ecuador. They provide shelter to wildlife resilience to rainfall variability and play an important role in climate change mitigation and adaptation (Celleri and Feyen, 2009). The natural functioning of these ecosystems are increasingly at risk not only as a consequence of global warming but also due to the continuing expansion of human activities (Buytaert et al., 2007, 2011). It
HESSD

9, 2475-2510, 2012

\section{Hydrologic response of tropical Andean micro-catchments in Southern Ecuador}

P. Crespo et al.

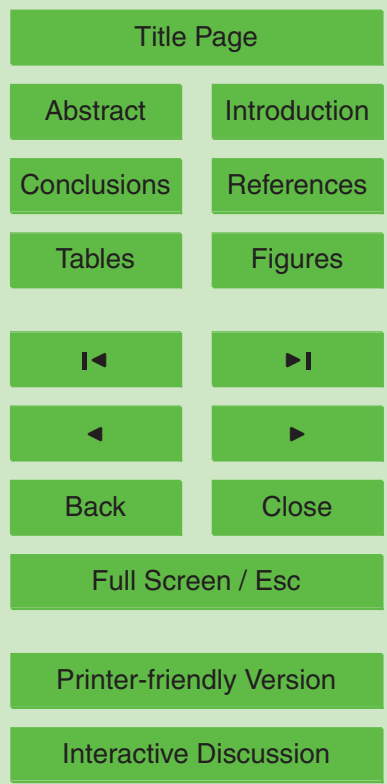


is expected that understanding of the hydrology of the Andean mountain ecosystems will provide knowledge on how best to manage these systems to secure their existing fresh water supplies (Bruijnzeel, 2001; Feddema et al., 2005). Notwithstanding the ecological and economic importance of these ecosystems understanding of the hy5 drological functioning is still incomplete, especially the prediction of the rainfall-runoff response is complex as a consequence of the high spatial variability of climate, soils, and vegetation (Crespo et al., 2011a).

According to Buytaert et al. (2006a) the runoff variability of páramo ecosystems is strongly masked by the topography, soil and vegetation. Buytaert (2004), Zimmer10 mann and Elsenbeer (2008) and Crespo et al. (2011a) confirmed this hypothesis and found that streamflow mainly is sustained by lateral subsurface flow in the soil matrix. Goller et al. (2005), Boy et al. (2008) and Crespo et al. (2011b) came to the same conclusion monitoring geochemical and isotopic tracers in forested subcatchments of the San Francisco basin in Southern Ecuador. Their findings are confirmed by Elsen15 beer et al. (1995), Elsenbeer (2001), Schellekens et al. (2004), Buytaert et al. (2006b) and Blume et al. (2008) on the basis of detailed flow monitoring in tropical ecosystems. Other publications report that runoff in tropical forested catchments predominantly is characterized by overland flow (Elsenbeer and Lack, 1996; Johnson et al., 2006; Chaves et al., 2008).

20 Crespo et al. $(2011 a, b)$, in their survey of the rainfall-runoff response of small catchments in the tropical Andes of Southern Ecuador, found that during dry periods streamflow mainly is the result of lateral flow through the Chorizon of the soil profile and the weathered top of the underlying bedrock. These authors further assumed that the unweathered bedrock does not contribute to streamflow, although locally depending 25 from the geological characteristics it might be possible that a fraction of streamflow is generated by the water stored in bedrock fissures. The water draining from the Chorizon and the weathered top of the bedrock originates from the excess rainfall percolating below the overlying organic horizons. During average precipitation events the soil profile gradually saturates yielding an increasing fraction of lateral subsurface flow
HESSD

9, 2475-2510, 2012

\section{Hydrologic response of tropical Andean micro-catchments in Southern Ecuador}

P. Crespo et al.

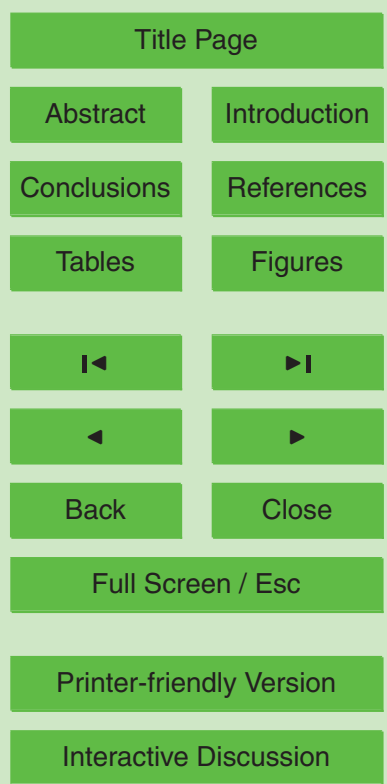


(Buytaert, 2004; Boy et al., 2008; Crespo et al., 2011a). Zimmermann and Elsenbeer (2008) found that under moderate rainfall conditions in a study area situated in the same area as the research conducted by Crespo et al. (2011a) most of the streamflow is composed of the lateral flow through the top horizons of the soil. Under intense 5 storm events streamflow is dominated by the lateral flow through the rooted organic horizon and litter layer, as stated by Goller et al. (2006), Boy et al. (2008) and Bücker et al. (2010). Research further revealed that during wet soil conditions and near rivers, overland flow most probably occur by saturation excess. Due to the overall low rainfall intensity and the high saturated hydraulic conductivity of the top layer it is unlikely 10 that Hortonian overland flow happens, although Crespo et al. (2011a) found that locally in páramo ecosystems overland flow during extreme events can arise. Zimmermann and Elsenbeer (2008) and Bogner et al. (2008) concluded that Hortonian flow only seldom occurs in cloud forests in Southern Ecuador. Similarly Buytaert et al. (2007) and Blume et al. (2007) came to the same conclusion for páramo ecosystems in Ecuador 15 and Chile.

The paper presents a conceptual model for simulating the runoff response to rainfall of Andean micro-catchments in Southern Ecuador, based on the hypotheses formulated in previous research (Crespo et al., 2011a,b). Underlying assumptions implemented in the conceptual model are: (i) deep water hardly contributes to streamflow; (ii) during prolonged dry spell periods streamflow mainly consists of lateral flow through the Chorizon and bedrock; (iii) lateral flow through the organic horizons and/or litter layer mostly characterizes streamflow in rainy periods; and (iv) saturation excess flow only locally occurs during extreme storm events. A step-wise increase in complexity of conceptual model was applied and tested, with the objective to define which level of
HESSD

9, 2475-2510, 2012

\section{Hydrologic response of tropical Andean micro-catchments in Southern Ecuador}

P. Crespo et al.

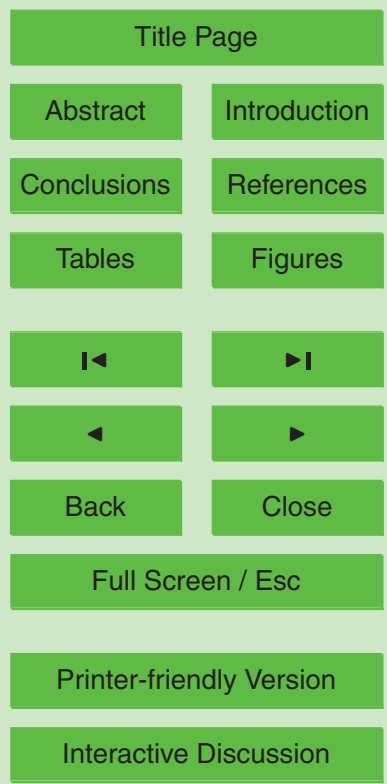




\section{Materials and methods}

\subsection{Case study catchment description}

Four micro-catchments were selected, representing pristine conditions in the wet páramo, upper montane and cloud forest region of Southern Ecuador. The micro5 catchments are situated between $2^{\circ} 24^{\prime \prime}$ and $3^{\circ} 58^{\prime \prime}$ latitude. The elevations vary between 1743 and $4100 \mathrm{~m}$ a.s.l. and the catchment area between 0.99 and $4.62 \mathrm{~km}^{2}$ (Fig. 1 and Table 1). The micro-catchments Zhurucay (M1) and Ortigas (M3) drain to the Pacific Ocean and are located on the east slope of the Cordillera Occidental while the Huagrahuma (M2) and San Ramon (M4) are tributaries to the Amazonian River Basin, whereby M2 is located on the western slope of the Cordillera Occidental and M4 on the western slope of the Cordillera Real. M1 is located in the upper basin of the Jubones river, $\mathrm{M} 2$ is a tributary to the Paute river, $\mathrm{M} 3$ drains into the BuluBulu river basin, and M4 discharges into the Zamora river basin. The shape of M2 $\left(2.58 \mathrm{~km}^{2}\right)$ and $\mathrm{M} 3\left(0.99 \mathrm{~km}^{2}\right)$ is stretched oval with an average surface slope of 43 to $45 \%$. The basin area of M1 and M4 is 1.34 and $4.62 \mathrm{~km}^{2}$ and the average surface slope is 18 and $61 \%$, respectively. The catchment shape of both these micro-catchments is elongated oval to rectangular and circular to oval (see Table 1).

$\mathrm{M} 1$ and $\mathrm{M} 2$ belong to the wet páramo ecosystem (neotropical alpine grassland) covering the Andes region above $3500 \mathrm{~m}$ a.s.l. with a landscape build up of relative flat to concave valleys (Luteyn, 1992; Hofstede, 1995; Medina and Vásconez, 2001). Both micro-catchments represent good pristine conditions; only sporadic extensive grazing by free roaming animals is observed in the lower part of both catchments. Tussock grass, cushion plants and low shrubs are the dominant vegetation (Table 1) (Buytaert et al., 2006b). Although the similarities between both, these catchments were

selected for the difference in average surface slope, respectively 18 and $43 \%$. Pri-

mary protected upper montane forest covers $76 \%$ of M3 (Asteraceae, Boraginaceae, Coriaceae, Euphorbiaceae, Junglandaceae, Fabaceae, Melastomataceae, Scrophulariaceae, Solanaceae, Verbenaceae) (Bruijnzeel, 2001; Crespo et al., 2008). Canopy

HESSD

9, 2475-2510, 2012

Hydrologic response of tropical Andean micro-catchments in Southern Ecuador

P. Crespo et al.

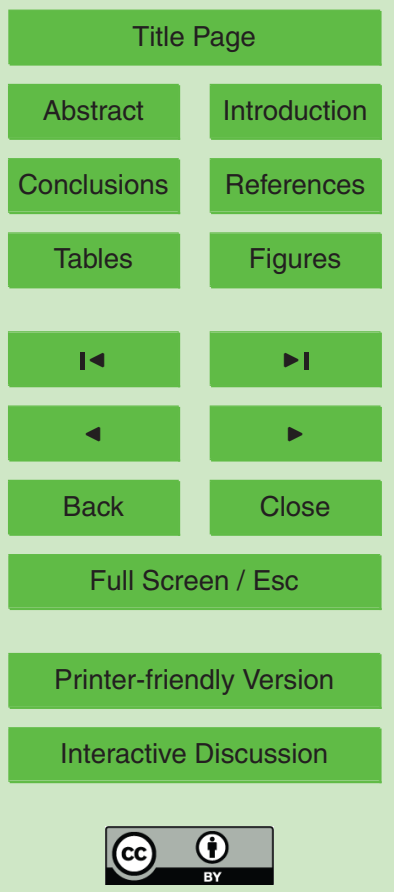


height varies between 5 and $10 \mathrm{~m}$, occasionally exceeding $15 \mathrm{~m}$ (Bussmann, 2005); stems are covered with lichens and epiphytes (Balslev and Øllgard, 2002). Fog interception at this altitude is negligible according to Bendix et al. (2008). Anthropogenic impacts are mainly present in the upper and remaining part of the basin consisting of 5 deforestation for grazing (Penicetum clandestinum) and the cultivation of maize and potatoes. M4 is covered with pristine montane cloud forest $(80 \%)$ with trees of the families Lauraceae, Euphorbiaceae, Melastomataceae and Rubiaceae, on average $20 \mathrm{~m}$ tall (Homeier et al., 2002). The basin area above $3140 \mathrm{~m}$, representing $18 \%$ of the basin area, is covered with sub-páramo evergreen elfin forest (Beck et al., 2008; 10 Homeier et al., 2002). The area is very susceptible for landslides, as a consequence of terrain steepness, the relative shallowness and high moisture content of the soils (Bussmann et al., 2008). Open spots, occupying $2 \%$ of the basin area, created by landslides are with time covered by secondary forest growth. A more detailed description of the four micro-catchments can be found in Buytaert et al. (2006b, 2007) and 15 Crespo et al. (2010, 2011a).

The climate in M1 and M2 is affected by the Pacific coastal regime from the west and the continental and tropical Atlantic air masses from the east (Vuille et al., 2000). The resulting precipitation pattern is bimodal, with a major wet season in December to February and a less pronounced wet season from August to September interrupted by dry spell periods of less than 16 days (Buytaert et al., 2005; Crespo et al., 2011a). The mean annual precipitation in the period 1964-2008 (INAMHI) varies from a maximum of $1600 \mathrm{~mm}$ to a minimum of $900 \mathrm{~mm}$. Mean annual precipitation in M3 in the period 1970-2008 fluctuates between 500 and $1900 \mathrm{~mm}$. The inter-annual seasonality is unimodal and influenced by the Pacific coastal regime. The wet season stretches from

December to May yielding 60 to $80 \%$ of the annual precipitation, and a dry season from June to November. Continuous dry periods of two months and longer are not an exception. The climate in M4 is affected by air masses originating in the Amazonian basin (Beck et al., 2008). The precipitation pattern is unimodal with relative constant inter-annual seasonality. The main wet season is from April to September with dry
HESSD

9, 2475-2510, 2012

\section{Hydrologic response of tropical Andean micro-catchments in Southern Ecuador}

P. Crespo et al.

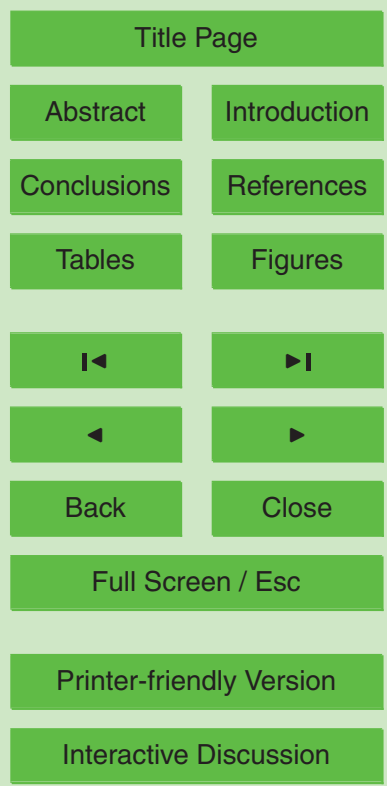


spells mainly occurring for less than 10 consecutive days (Fleischbein et al., 2005). In the period 1964-2008 annual precipitation varied from 900 to $4300 \mathrm{~mm}$ (INAMHI) with an average of $2200 \mathrm{~mm}$ at an altitude of $1960 \mathrm{~m}$; however average rainfall increases to $4700 \mathrm{~mm}$ (1994-2004) at the Cerro del Consuelo station located at $3150 \mathrm{~m}$ a.s.l., 5 at the fringe of the catchment (Rollenbeck, 2006; Bendix et al., 2008). Horizontal rain and cloud/fog water deposition contributes up to $41.2 \%$ of the basin water yield (Bendix et al., 2008). Rainfall intensity is low in all four study basins with $90 \%$ of the rains having intensities less than 10 (M1, M2 and M4) and $15 \mathrm{~mm} \mathrm{~h}^{-1}$ (M3). A more detailed description of the climate in each of the micro-catchments is available in Buytaert ot al. (2006a, 2007) and Crespo et al. (2008).

The geology of M1 and M3 belongs to the Late Oligocene to Early Miocene Saraguro Fm., with lavas and andesitic volcaniclastic deposits compacted by glacier activity during the last ice age (Coltorti and Ollier, 2000; Hungerbühler et al., 2002). According to Buytaert et al. (2005) hydraulic conductivity of the Saraguro Fm. is low. The microcatchment M2 is located on the Quimsacocha Fm. (Pratt et al., 1997). Covered by volcanic and volcaniclastic rocks, the formation consists of basalt flows with plagioclase, feldspar phenocrysts and andesitic pyroclastic deposits. According to IAMGOLD (2006) the age of the deposits is undefined; hydraulically they are nearly impermeable and possess a low density of fissures in the upper layer of the formation. The geology

in M4 correspond to the Chiguinda unit, which is mainly composed of Paleozoic metamorphic rocks such as semipelite, phyllite and quartzite with low alteration (Litherland et al., 1994; Hungerbühler, 1997; Bendix et al., 2008).

The main soils in the study catchments are Andosol, Leptosol, Histosol, Cambisol and Regosol (FAO/ISRIC/ISSS, 1998). The soil distribution per micro-catchment is listed in Table 1, while the soil properties of the main horizons are summarized in Table 2. The cold and wet climate and the low atmospheric pressure, characteristic for mountains, favor organic matter accumulation resulting in soils with high soil organic matter content, 15 to $50 \%$, low bulk density $\left(0.1\right.$ to $\left.0.44 \mathrm{~g} \mathrm{~cm}^{-3}\right)$, high water content ( 0.63 to $0.9 \mathrm{~cm}^{3} \mathrm{~cm}^{-3}$ ) at saturation, and low to moderate $\mathrm{pH}$ (4.3 to 6.0) (Table 2). The
HESSD

9, 2475-2510, 2012

\section{Hydrologic response of tropical Andean micro-catchments in Southern Ecuador}

P. Crespo et al.

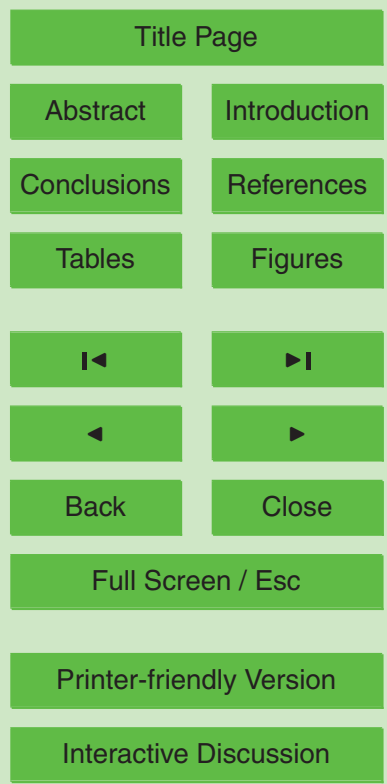


horizon sequence of the Andosols in $\mathrm{M} 1$ and $\mathrm{M} 2$ is $\mathrm{Ah}, \mathrm{A}$ and $\mathrm{C}$, and of the Histosols in $\mathrm{M} 1$ is $\mathrm{H}, \mathrm{A}$ and $\mathrm{C}$. The depth of the organic horizon ranges from 36 to $90 \mathrm{~cm}$ in $M 1$ and from 36 to $55 \mathrm{~cm}$ in M2. Andosols (74\%) and Leptosols (26\%) are present in M3 with horizon sequence $\mathrm{O}, \mathrm{A}, \mathrm{Bw}$ and $\mathrm{C}$ for Andosols, and $\mathrm{O}$ or Ah on top of 5 the parent material for Leptosols. Leptosols are mainly located on steep slopes where the soils in general are less developed. The main soils in M4 are Histosols (60\%), Cambisols (30\%) and Regosols (10\%). The Histosols under cloud forest are less deep having a horizon sequence of $\mathrm{O}, \mathrm{H}$, Ah and $\mathrm{C}$ (Makeschin et al., 2008; Wilcke et al., 2002). The Cambisols in M4 are located below $2100 \mathrm{~m}$ a.s.l. and are typical Dystric 10 or Humic Cambisols with the horizon sequence O, Ah, Bw and C (Wilcke et al., 2002). Regosols are mainly situated below $2100 \mathrm{~m}$ a.s.l., decreasing in area with the altitude until $2300 \mathrm{~m}$ a.s.I. O, Ah and C are the typical horizon sequence of the Regosols. A detailed description of the soil characteristics are given in Crespo et al. (2011a).

\subsection{Monitoring}

15 M1 and M3 were equipped with a weather station, and M4 with 3 weather stations. A weather station was present at the Chanlud dam, close to M2. Hourly data was available for M1, M3 and M4, while daily data for M2. Reference evapotranspiration (ETp) was estimated using the Penman-Monteith equation with constant canopy resistance (Allen et al., 1998). An intra-day curve was used to estimate hourly ETp for ${ }_{20} \mathrm{M} 2$ and repeated for the entire monitoring period. This approach produces an acceptable hourly distribution of ETp due to the low seasonal climate variability, typical for páramo, as stated by Buytaert and Beven (2011). Additionally, in M1 and M3 two rainfall gauges (HOBO RG3 tipping bucket gauge with a resolution of $0.2 \mathrm{~mm}$ ) were installed, respectively in the upper and lower part of the basin, and three rainfall gauges relatively uniformly distributed over the basin area in M2 (same type of raingauge as in M1 and M3) and M4 (details on the equipment and protocol of rainfall and fog collection and data processing are given in Bendix et al., 2008). The precipitation data for all catchments were aggregated over time intervals of one hour. The short data gaps were

\section{HESSD}

9, 2475-2510, 2012

\section{Hydrologic response of tropical Andean micro-catchments in Southern Ecuador}

P. Crespo et al.

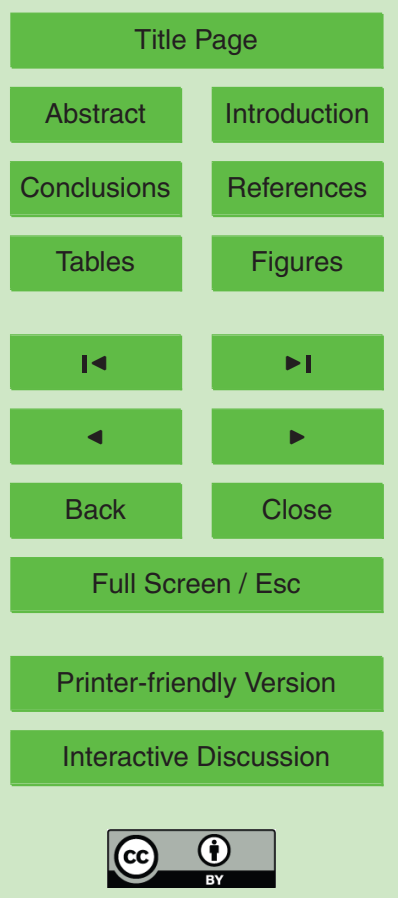


filled using linear interpolation. The Thiessen polygon method was applied to derive areal precipitation data for the catchments $M 1$ to $M 3$, and the area weighted elevation method for the generation of the areal rainfall and fog for M4. A concrete Thompson (V-notch) weir $\left(90^{\circ}\right)$ with sharp metal edges was installed in the micro-catchments $\mathrm{M} 1$ 5 to M3, while streamflow in the catchment M4 was measured in a natural stable river cross section. Each measuring site was equipped with pressure transducers, recording the water level with a 5 min interval and an accuracy of $\pm 1 \mathrm{~mm}$. In M2 on 12 May 2002 a backup sensor was installed to replace the failing sensor. To reduce the uncertainty on streamflow measurements, particular during storm events frequent control 10 measurements were made. The Kindsvater-Shen relation (US Bureau of Reclamation, 2001) was used for the conversion of the water level to discharge for M1 to M3. An empirical stage-discharge relationship was developed for M4.

\subsection{Description of the conceptual model}

The concept of the model for simulating the runoff of the micro-catchments M1 to M4 15 is based on the findings of Goller et al. (2006), Buytaert and Beven (2011) and Crespo et al. $(2011 a, b)$. Precipitation is split in canopy and surface interception and rainfall stored in the different soil horizons and top of the bedrock. The subsurface and groundwater flow components are mimicked by a maximum of 3 reservoirs If present overland or liter layer flow is calculated as a fraction of the rainfall. Figure 2 depicts the structure of the subsurface model assuming that the soil hydrology can be mimicked with 3 reservoirs (3-Res model structure). Total flow $\left(Q_{\text {total }}\right)$ is the sum of the outflow of each reservoir $\left(Q_{1}, Q_{2}\right.$ and $\left.Q_{3}\right)$ and in the case of overland flow increased with the direct flow. The storage $(S)$ in each of the three linear reservoirs $S_{1}-S_{3}$ is governed by the water balance equations as shown in the Eqs. (1), (2) and (3):

\section{HESSD}

$9,2475-2510,2012$

\section{Hydrologic response of tropical Andean micro-catchments in Southern Ecuador}

P. Crespo et al.

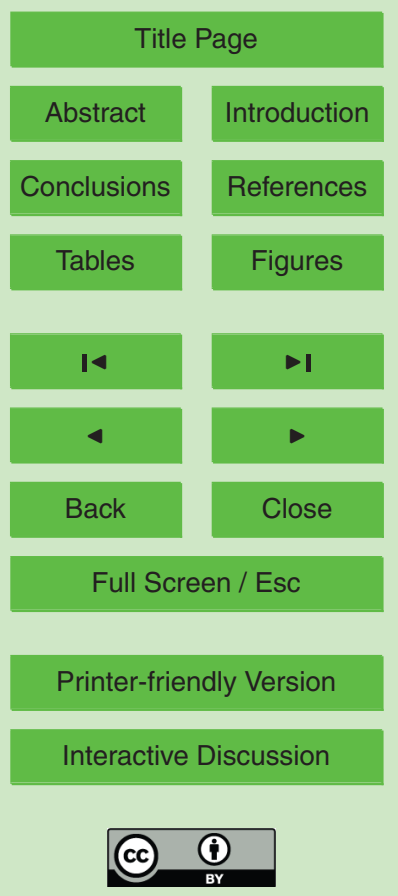


where $P$ is the precipitation at time interval $t$, IL the interception loss, $\mathrm{ET}_{\mathrm{a}}$ the actual evapotranspiration, LL the overland or litter layer flow, SOF the saturated overland flow, $Q$ the lateral outflow from the reservoir, $I_{1}$ is the percolation from reservoir 1 into reservoir 2 , and $I S_{2}$ the percolation from reservoir 2 into 3 . Interception loss is calculated as 5 a fraction of the precipitation below a threshold value representing the rainfall that saturates the canopy or fulfills surface storage. Threshold value for the canopy saturation was fixed at $10 \mathrm{~mm}$, while the interception loss fraction was estimated between 25 to $52 \%$ of the incident precipitation, both according to the study conducted by Fleischbein et al. $(2005,2006)$ in the same area as M4.

10 Actual evapotranspiration $\left(\mathrm{ET}_{\mathrm{a}}\right)$ is satisfied by the water stored in the canopy and surface storage (IL). When the amount of water in IL is less than the actual demand, the remaining fraction is extracted from the first reservoir, the so-called rootzone, via transpiration. $\mathrm{ET}_{\mathrm{a}}$ is proportional to the reference evapotranspiration $\mathrm{ET}_{\mathrm{p}}$ varying linearly with the soil moisture content $\left(S_{1} / S_{1 \text { max }}\right)$ as depicted in Eq. (4)

$15 \quad \mathrm{ET}_{\mathrm{a}}(t)=\frac{S_{1}(t)}{S_{1 \max }}\left[\mathrm{ET}_{\mathrm{p}}(t)-\mathrm{IL}(t)\right]$

The outflow $Q(t)$, Eq. (5), for each reservoir $(i)$ is simulated multiplying a transfer function for routing the model storage $(f)$ by a flow contribution equation $(\chi)$. Equation (6) shows the transfer function and Eq. (7) the flow contribution equation used in the conceptual model

$Q_{i}(t)=f_{Q_{i}} \times \chi_{Q_{i}}$

$f_{Q_{i}}(t)=\tau_{Q_{i}}^{-1} \times \exp \left[a_{Q_{i}} \frac{S_{i}(t)}{S_{i \max }}\right]$

$\chi_{Q /}(t)=\left[S_{1}(t)-T_{S_{1}}\right]$ for $S_{1}>T_{S_{1}}$ and $S_{1}<S_{1 \max }$

where $\tau$ is a time constant parameter, $a$ is a model parameter for the different outflows, $S_{i \max }$ the upper water storage limit in reservoir $i$, interpreted as the maximum

\section{HESSD}

9, 2475-2510, 2012

Hydrologic response of tropical Andean micro-catchments in Southern Ecuador

P. Crespo et al.

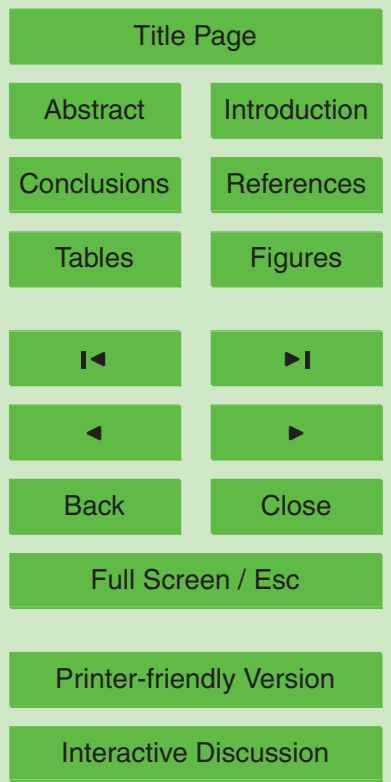


soil moisture content or the maximum water storage in the rock layer, and $T_{S_{1}}$ is the minimum soil moisture content required to generate lateral outflow in reservoir $i . S_{i \max }$ for soils is derived as the difference between saturation and wilting point multiplied by the horizon depth. When $S_{1}$ is less than $T_{S_{1}} Q_{1}(t)$ is equal to and $S_{1}$ represents the 5 non-mobile water in the reservoir.

Direct overland flow (SOF) and saturation excess in ponding areas and/or litter layer flow (LL) occur when the rainfall intensity is higher than the infiltration rate of the organic horizon LL is estimated as a fraction of the rainfall and SOF is the volume that exceeds the maximum storage $\left(S_{1 \text { max }}\right)$ in the top reservoir, both multiplied by the runoff coeffi10 cient $C_{\mathrm{LL}}$. Finally the percolation $\left(/ S_{i}\right)$ from one reservoir into the underlying reservoir is calculated as the volume above a threshold value $\left(T L S_{i}\right)$ assuming a linear variation with the soil moisture content $\left(S_{i} / S_{i \max }\right)$ (Eq. 8).

$S_{i}(t)=\left[S_{i}(t)-T L S_{i}\right] \times \frac{S_{i}(t)}{S_{i \max }}$ for $S_{i}>T L S_{i} \quad$ and $\quad S_{i}<S_{i \max }$

The number of parameters to calibrate is 14 when considering a 3-reservoir (3-Res) model and 10 parameters when mimicking the runoff with a 2-reservoir (2-Res) approach. The number of parameters increases by 2 when including the model description of interception losses (IL). The model was developed in the R programming language, using version 2.14.

\subsection{Model performance analysis}

20 According to Klemeš (1986) the hourly rainfall dataset available per study catchment was split, respectively for model calibration and validation, as outlined in Table 3. Prior to calibration a warm-up period of 6 months was used for all micro-catchments. Two model set-ups, the 2- and a 3-Res (2 and 3 reservoirs) model were tested Interception losses were only considered in the forested micro-catchments M3 and M4 Surface interception was considered negligible for the four micro-catchments. The Generalized Likelihood Uncertainty Estimation method (GLUE) (Beven and Binley, 1992) was

\section{5}

HESSD

9, 2475-2510, 2012

\section{Hydrologic response of tropical Andean micro-catchments in Southern Ecuador}

P. Crespo et al.

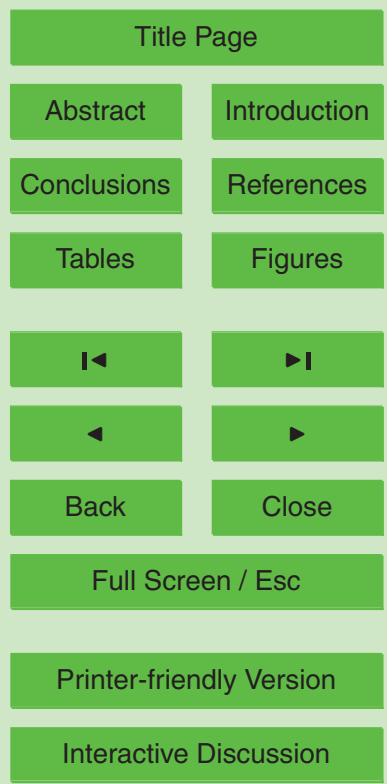


used to generate uncertainty bounds. The behavioral limits were chosen such that the uncertainty range encompasses $90 \%$ of all used observations. Model performance was characterized by the Nash Sutcliffe efficiency coefficient (EF) (Nash and Sutcliffe, 1970). As stated by Buytaert and Beven (2011) uncertainty in modeling the hydro5 logic response of mountain micro-catchments comes primarily from the input data, as a consequence of the climate variability and heterogeneity in aerial precipitation. Since it was not possible to measure the uncertainty caused by model inputs the authors just considered the total prediction uncertainty associated with input and model parameters. The viability of the model structures, respectively the 2 or 3-Res model, was

\section{Results and discussion}

\subsection{Rainfall-runoff}

Table 1 depicts the annual precipitation and discharge for the four micro-catchments, as recorded during the corresponding observation periods. The runoff coefficient for $15 \mathrm{M} 1$ and $\mathrm{M} 2$ is 0.74 , the result of an average annual observed precipitation of 1241 and $1460 \mathrm{~mm} \mathrm{yr}^{-1}$ and discharge of 913 and $1059 \mathrm{~mm} \mathrm{yr}^{-1}$, respectively. The precipitation regime in $\mathrm{M} 3$ is well-marked by a wet and dry period. $80 \%$ of the precipitation falls during the wet season, yielding a runoff coefficient of 0.46 ; the result of $803 \mathrm{~mm} \mathrm{yr}^{-1}$ discharge and $1715 \mathrm{~mm} \mathrm{yr}^{-1}$ rainfall. According to Crespo et al. (2011a) the moderate runoff in this micro-catchment is the consequence of the moderate to high evapotranspiration rate during the dry season. Annual precipitation in M4 is close to three times higher than in the other 3 micro-catchments, with an average annual value during the observation period of $3796 \mathrm{~mm} \mathrm{yr}^{-1}$. The fast response of the catchment to rain events results in an average annual discharge of $3066 \mathrm{~mm} \mathrm{yr}^{-1}$ during the observation period, leading to a the high runoff/precipitation ratio of 0.81 .

HESSD

9, 2475-2510, 2012

\section{Hydrologic response of tropical Andean micro-catchments in Southern Ecuador}

P. Crespo et al.

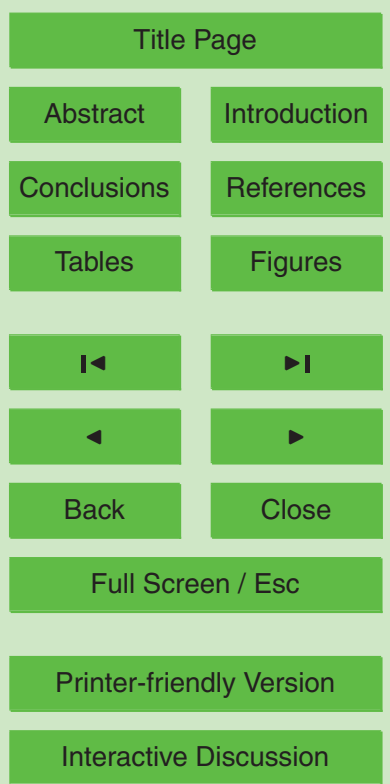


Intensities of most storm events are smaller than $10 \mathrm{~mm} \mathrm{~h}^{-1}$ for the micro-catchments $\mathrm{M} 1, \mathrm{M} 2$ and M4 and below $15 \mathrm{~mm} \mathrm{~h}^{-1}$ for M3; less than the saturated hydraulic conductivity of the top layer, which for M1 and M2 varies between 8 and $38 \mathrm{~mm} \mathrm{~h}^{-1}$, M3 from 28 to $105 \mathrm{~mm} \mathrm{~h}^{-1}$ and M4 between 160 and $167 \mathrm{~mm} \mathrm{~h}^{-1}$. Given the low to moderate 5 rainfall intensities it is very unlikely that Horton overland flow occurs, being the case very locally during high intensity rain events (Buytaert et al., 2006c; Goller et al., 2005; Crespo et al., 2011a). The authors expect that saturation excess overland flow takes place near the river bed. In general all catchments show a quick response of discharge to rainfall, suggesting a fast transport of water through the litter and organic layers of 10 the soils. During dry conditions the recession constant of discharge is high, suggesting a large water regulation capacity of the soils, as displayed in Table 2 . The foregoing is confirmed by Buytaert (2004), Buytaert et al., (2006c), and Crespo et al. $(2008,2010)$.

\subsection{Model calibration and evaluation}

The model performance indicators, bias, efficiency and accuracy (Moriasi et al., 2007) 15 calibration and validation period listed in Table 3 . Figure 3 shows the observed (dotted 2- (gray lines) and 3- (black lines) Res model. Figure 4 depicts for the microcatchments M1 to M4 the observed the $90 \%$ uncertainty band on the predicted discharge, respectively for the 2- (left panels) and 3-Res (right panels) model Results in Table 3 clearly show that for each of the four micro-catchments the 3-Res model outperforms the 2-Res model, and this during the calibration and evaluation periods. However, the difference in performance of both model structures is not significant for the M1 and M2 micro-catchments. Both model structures slightly better predict the observed discharge for M1 during the evaluation period, and perform equally well for M2 during the model calibration and validation period. The 3-Res model shows a statistical significant better prediction of the discharge for the M3 micro-catchment, and somehow less significant
HESSD

9, 2475-2510, 2012

\section{Hydrologic response of tropical Andean micro-catchments in Southern Ecuador}

P. Crespo et al.

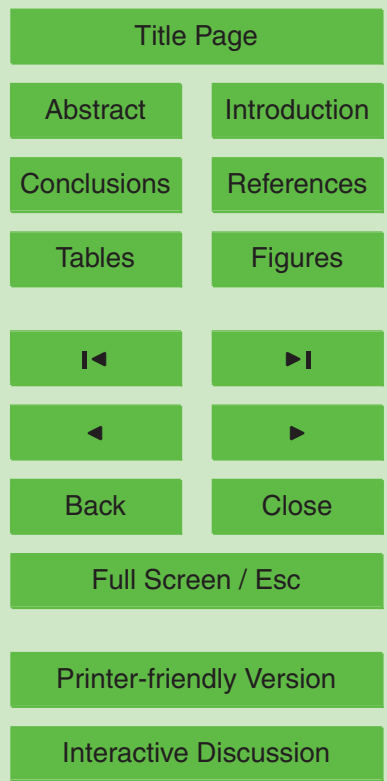


better than the 2-Res model structure for the M4 catchment. For both these catchments the model performance of both model structures in the calibration period was generally slightly better than during the model evaluation period.

The 5 and $95 \%$ uncertainty limits of the predicted discharge with application to the 5 M1 micro-catchment, using the 2- and 3-Res model, envelopes the observed time series of discharge, as shown in the Figs. 3 and 4 . Both model structures seem to predict the hydrologic response well for the majority of precipitation events. The recession curves the fast response to rainfall events in dry spell periods, and the time of peaks are in general correctly captured by both model structures (Fig. 4). The 2-Res model 10 seems to slightly underestimated peak flows during wet periods, while peaks during drier periods are overestimated or not simulated. Adding a 3rd reservoir on top of the $2-$ Res model structure, with low residence time $(18 \mathrm{~h})$ peak flows are better simulated however considerably overestimated during dry periods (Fig. 3) In line with findings of Nandakumar and Mein (1997) and Bruijnzeel and Veneklaas (1998) the incorrect pre15 diction of peak flows during wet and dry periods is due to an underestimation of the areal precipitation a wellknown phenomenon in mountain areas (Celleri et al., 2007). Additionally, as suggested by Buytaert and Beven (2011), linear reservoir structures in general tend to have problems in simulating peaks. Another explanation might be that the lumped approach does not correctly mimic the dynamics between the hillslope and concave saturated plateaus and depressions, which according to Beven and Freer (2001) and Beven (2001a) during rain storms directly contribute to peak flow. The uncertainty interval is considerably wider during low flows than high flows, and adding a 3rd reservoir reduces the width of the $90 \%$ confidence interval. It is noticed that both the 2- and 3-Res models better predict streamflow during the model validation than 25 calibration period.

The 2- and 3-Res model structures perform equally well in modeling the rainfallrunoff process of the M2 micro-catchment. Both model structures give similar EF and Bias values. Nearly the same value, varying between 0.71 and 0.74 , was obtained for the modeling efficiency (EF) using the 2- and 3-Res model structure during model
HESSD

9, 2475-2510, 2012

\section{Hydrologic response of tropical Andean micro-catchments in Southern Ecuador}

P. Crespo et al.

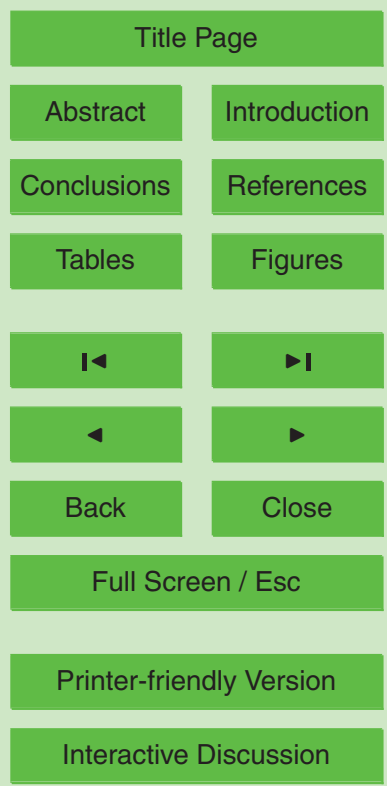


calibration and validation. Bias values for both periods and model structures are low, and in the range 0.01 and 0.03 . The uncertainty limits are in general well capturing the observed discharge, with accuracy values ranging between 62 and $65 \%$ and 71 and $73 \%$ for the 2- and 3-Res model, respectively. As shown in Fig. 3 for M1, the 5 and $95 \%$ 5 uncertainty limits envelope the flow duration curve of the M2 micro-catchment. Both model structures represent properly most precipitation events and recession curves are well simulated, however the lower $(5 \%)$ uncertainty limit significantly underestimates discharge values during low flows. The addition of a 3rd reservoir with high residence time (140 days), with the objective to simulate possible deep-water flow, did not improve 10 the simulation results (data not shown). A plausible reason could be the overestimation of the evapotranspiration $\mathrm{ET}_{\mathrm{p}}$ was calculated using daily data from a station outside the catchment, situated at a lower - warmer - elevation. Another explanation could be the inability of linear reservoirs to correctly model the antecedent soil moisture content and soil drainage as explained earlier (Fenicia et al., 2008a,b; Lane et al., 2009). Buytaert 15 and Beven (2011) in a study carried out in the same M2 micro-catchment using a 2 and 3 parallel linear reservoir model, were also not able of properly simulating low flows during dry conditions. On the other hand, the tested 2- and 3-Res model structures correctly mimic the fast response from low to peak flows following a transition from a non-rainy to a rainy period, suggesting that the reservoir storage concept correctly models the hydrology of the M2 micro-catchment. Whereas the 2-Res model correctly simulates the peaks during dry periods, it underestimates peak flows during wetter conditions. Adding a 3rd reservoir on top of the 2-Res model with low residence time $(25 \mathrm{~h})$, the 3-Res model structure in general improves the simulation of the peak flows during wet conditions; however overestimate the peaks during drier periods. The latter could be attributed to the interception loss of the low intensity rains and the fact that the presented conceptual model does not account for the hydrological connectivity between slopes, small plateaus and depressions. As can be seen in Fig. 4, the 3Res model is capable of simulating more accurately low flows than the 2-Res model structure.

\section{HESSD}

9, 2475-2510, 2012

\section{Hydrologic response of tropical Andean micro-catchments in Southern Ecuador}

P. Crespo et al.

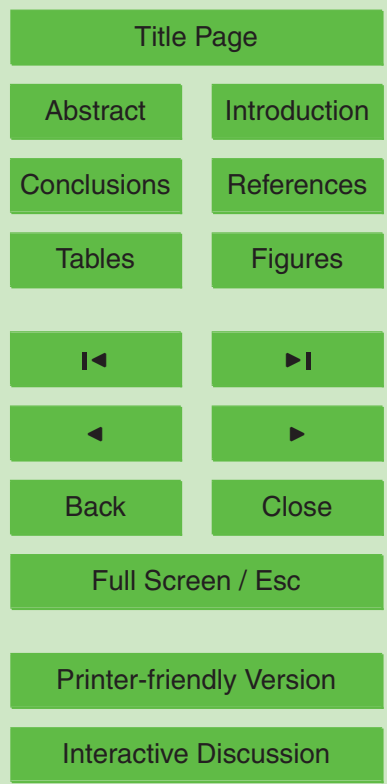


The model performance indicators for M3 in Table 3 clearly illustrates that the 2-Res model structure strongly underrates the prediction of the discharge. Modeling efficiency is 0.36 and 0.28 for the calibration and validation period, respectively. Due to the selected threshold value for EF in the GLUE analysis (EF > 0.5) the uncertainty bounds 5 for the 2-Res model structure could not be generated. The 2-Res model consistently underestimates discharge during low flows, indicating that the recession curves are not well simulated (Fig. 4). Additionally, the 2-Res model showed difficulties in correctly simulating the recession curves during wet and dry periods Adding a 3rd reservoir, with a residence time of 398 days, considerably improved for the M3 micro-catchment the 10 modeling of the runoff. It is noticed that low flows are better simulated during the wet season, than the dry season, indicating that during the wet season the streamflow contributing water source areas and the hydraulic connectivity of streamflow contributing areas are different (Staudinger et al., 2011). The 3-Res model structure quite accurately simulates the recession curves during the long dry season, a 6 month period totaling 20 to $40 \%$ of the annual precipitation. Crespo et al. (2008) in a study conducted in the same catchment reported difficulties simulating the recession curves and low flows using the SWAT model. These authors suggested a high contribution of the rock water as possible explanation Roa-García et al. (2011) in a study conducted in the Andean region of Colombia found that natural forest basins store more water and release the stored water over a much longer period than grassland. Medium flows were in general underestimated, likely as a consequence of the incorrect modeling of the rainfall interception affecting the vertical water distribution and net rainfall spatial heterogeneity, resulting in the wet season in a moderate to large spatial variability of stored water (Fenicia et al., 2008b). Peak flows were overestimated and the time of peaks were simulated approximately $2 \mathrm{~h}$ earlier than the observed, reflecting the effect of the delay caused by the litter layer, a layer not fully considered in the presented 2and 3-Res model structures.

Application of the 3-Res model to the M4 micro-catchment yields similar model efficiency values as found for the M1 and M2 micro-catchments. The EF values are a bit
HESSD

9, 2475-2510, 2012

\section{Hydrologic response of tropical Andean micro-catchments in Southern Ecuador}

P. Crespo et al.

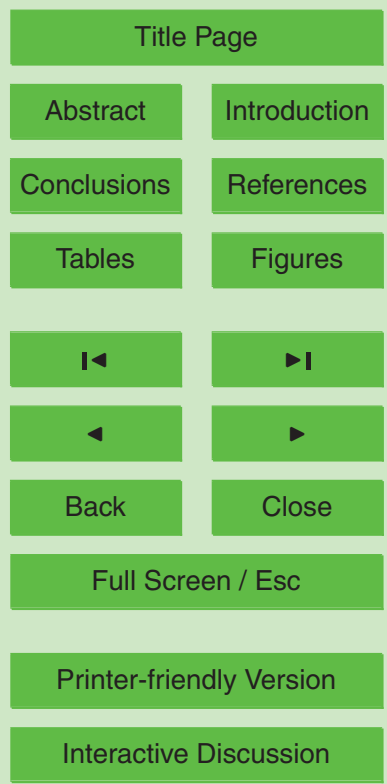


lower using the 2-Res model structure for predicting the catchment runoff. Both model structures perform a little better during the calibration phase, respectively 0.63 versus 0.60 for the 2-Res model structure and 0.71 versus 0.69 for the 3-Res model structure. Whereas the lower (5\%) and upper (95\%) confidence limits of the 2- and 3-Res mod5 els envelop the cumulative frequency curve of the observed hourly flows, application of the 3-Res model leads to a higher accuracy and this during both, the calibration and validation periods. The accuracy of the 2-Res model structure in predicting the runoff is considerably less and is, respectively equal to 56 and $47 \%$ during the calibration and validation period, versus 69 and $71 \%$ for the 3-Res model. Both model struc10 tures correctly predicted the major precipitation events, failed to model some of the observed peaks, and simulated peaks that were not directly associated with precipitation events Similar deviations between observed and simulated discharge were reported by Plesca et al. (2011) in a study conducted in a basin where M4 is a tributary According to these authors and in agreement with Rollenbeck (2006) deviations are likely due to the high spatial variability in rainfall and fog, and the poor spatial distribution of precipitation monitoring stations As shown in Fig. 2, the limits of the $90 \%$ confidence interval of the predictions of both models are in general very similar, notwithstanding recession curves during wetter periods were sometimes underestimated, but correctly simulated during drier periods Application of the 2-Res model to predict for the M4 micro-catchment streamflow leads to a systematic overestimation of peak flows, while the low flows are significantly underestimated. Adding a 3rd reservoir with high residence time (365 days), mimicking the water contribution of the bedrock considerably improved the predictive capacity of the conceptual model during low flows, a finding in line with the results obtained by Crespo et al. (2011b) and Bücker et al. $(2010,2011)$,

\subsection{Evaluation of the conceptual model}

The modeling results and the performance indicators for all micro-catchments point out that the two conceptual model structures are variably capable of modeling the 2491
HESSD

9, 2475-2510, 2012

\section{Hydrologic response of tropical Andean micro-catchments in Southern Ecuador}

P. Crespo et al.

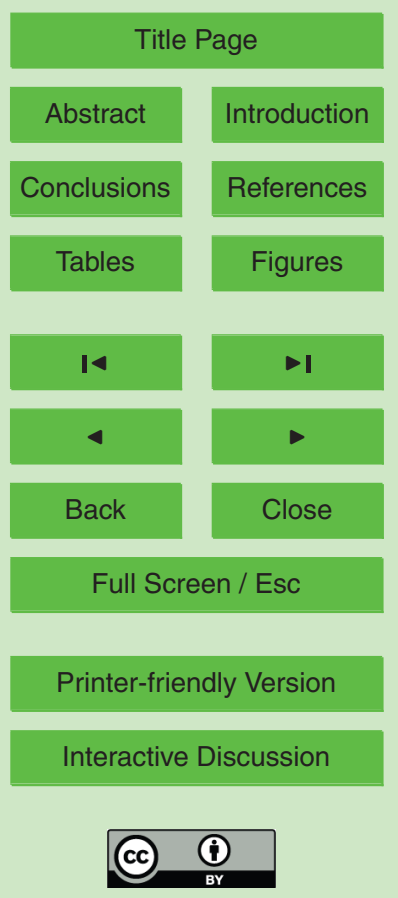


hydrology of the soil profile and the underlying bedrock. Although the vegetation cover, topography and climate regime of the four micro-catchments are different, they have in common that the rainfall-runoff process is controlled by the succession of organic rich horizons laying on a thin layer of weathered bedrock, on top of the bedrock (Crespo 5 et al., 2011a; Bücker et al., 2011). As stated earlier, the 2- and 3-Res models show similar performances for the micro-catchments M1 and M2. Here, the upper reservoir of the 2-Res model represents the soil organic horizons (Ah and $\mathrm{H}$ ) with a soil organic matter content varying between 15 and $50 \%$, densely rooted, and extreme low bulk density (in the range 0.1 to $0.44 \mathrm{~g} \mathrm{~cm}^{-3}$ ). The origin of the organic layers is very 10 much different from the underlying mineral layer. The latter being the product of the weathering of the rock layer beneath the thick and dark highly organic epipedons. The organic horizons are the result of the poor decomposition of organic matter because of the predominantly cold and wet climate. The water storage release of the mineral layer and top of the bedrock is presented by the second reservoir in the 2-Res model.

15 No groundwater was considered neither for M1 or M2 as was suggested in previous research (Crespo et al., 2011a; Buytaert et al., 2006c) Adding a third reservoir (i.e. shifting from a 2- to a 3-Res model) results in an improvement of the peak flows. As stated by Buytaert and Beven (2011) and Crespo et al. (2011a) during peak flows the fast response of both catchments is mainly controlled by the interaction between the hillslopes, the dynamic zones in the catchments, and the stagnant zones in the valley bottoms, the overland flow in saturated areas and the fast lateral flow through the rooted organic horizon. Whereas the first phenomenon is not represented by the model the second is mimicked in the model by the estimation of SOF and LL, and the third phenomenon is indirectly mimicked by introducing a third shallow reservoir with small storage capacity and low transit time. Table 4 summarizes the cumulative contribution of the different reservoirs to the total flow assuming a 3-Res model concept. For the micro-catchments $\mathrm{M} 1$ and $\mathrm{M} 2,31$ and $28 \%$ of the total discharge is contributed by the upper reservoir by subsurface flow through the rooted organic horizon, 57 and $60 \%$ of the streamflow is delivered by the non-rooted organic horizon, and 11 and $10.8 \%$ is
HESSD

9, 2475-2510, 2012

\section{Hydrologic response of tropical Andean micro-catchments in Southern Ecuador}

P. Crespo et al.

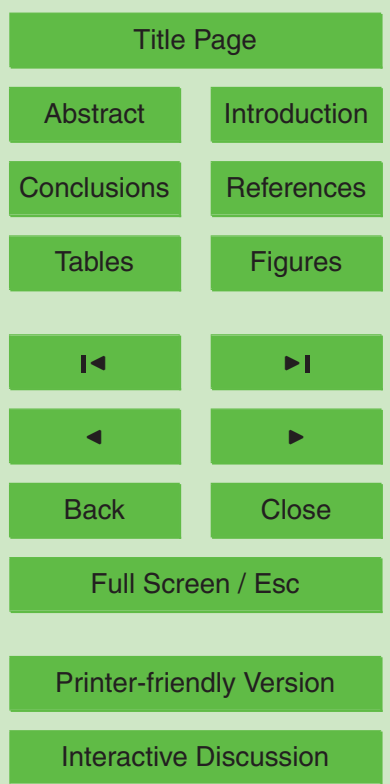


the result of the lateral flow through the weathered mineral layer on top of the bedrock, respectively. Good estimation of the antecedent soil moisture content during both peak and slow flows seems to be important, as stated by Crespo et al. (2011a); Buytaert et al. (2006c); and Celleri (2007).

5 The simulation results for the M3 micro-catchment show the relevance of adding a third reservoir with high transit time, representing the contribution of the bedrock, yielding $30 \%$ of the total discharge (Table 4). The third reservoir captures the runoff generation during dry periods. The relative contribution of the second reservoir, being the mineral soil layer, is more significant during dry periods being less important during 10 wet conditions as is depicted in the Fig. 4. The second reservoir generates on average $26 \%$ of the total discharge However, during wet periods the first reservoir (organic soil layer) dominates the runoff process with an average contribution of $44 \%$ Direct flow is unimportant contributing only $0.2 \%$ of the total discharge. The low lateral flow contribution of the litter layer is likely the consequence of the high infiltration rate of this 15 layer. Crespo et al. (2011a) in a study carried out in the same basins concluded that under dry conditions the slow flow component mainly is generated by the lateral flow in the Chorizon and contributions of the bedrock, the so-called baseflow. This conclusion is supported by the simulation results of the 3-Res conceptual model presented herein. Results however indicate that the model concept underestimates the contribution of the top of the rock layer. The high hydraulic conductivity of the $\mathrm{O}$ and A horizons suggests the rapid infiltration of the rainfall during wet periods, replenishing the shallow watertable on top of the bedrock, filling also the fissures in the top of the bedrock. It is this water that feeds runoff during dry periods. During wet conditions the lateral flow through the litter layer and organic horizon are the main components of the total discharge in the M3 micro-catchment.

Similarly, for the M4 micro-catchment adding a third reservoir with high residence time improves the simulation of the low flows and peaks, suggesting a significant contribution of the bedrock representing on average $13 \%$ of the total discharge, confirming earlier findings of Crespo et al. (2011b) and Bücker et al. $(2010 ; 2011)$. These authors

\section{HESSD}

$9,2475-2510,2012$

\section{Hydrologic response of tropical Andean micro-catchments in Southern Ecuador}

P. Crespo et al.

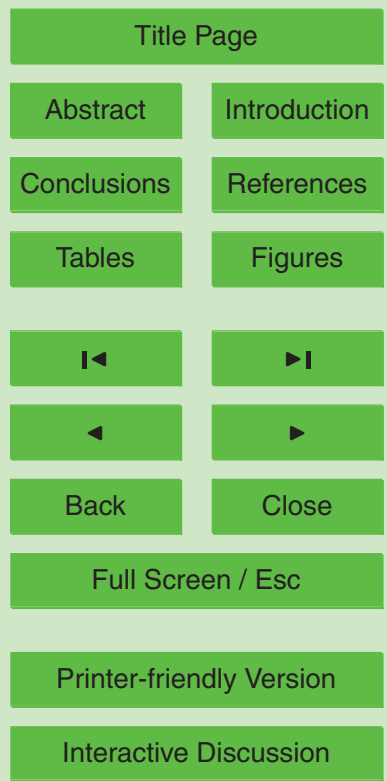


also showed that the weathering of the top of the bedrock not only influences runoff generation during low flows, but also contributes to the discharge in wet periods. The mineral soil layer (second reservoir) contributes on average $10 \%$ to total discharge. The lateral subsurface flow through the organic soil horizons is the major flow source, 5 representing on average $66 \%$ of the discharge. Direct flow through the litter layer represents around $10 \%$ of total flow primarily sustaining the peaks during wet conditions. Overland flow is low to non-existent as suggested by Fleischbein et al. (2006) and Crespo et al. (2011b). Goller et al. (2005) in a study close to M4 obtained similar results in a flow separation experiment based on stable water isotopes They found that the 10 water flow paths are dominated by the vertical flow through the soil profile while during rainstorm events mainly lateral flow through the organic layers take place. These authors identified the high contribution of a near-surface flow (through litter layer) during intense rain storm events. Similar results were obtained by Wilcke et al. (2002); Fleischbein et al. (2006); Boy et al. (2008), and Crespo et al. (2011b). All these findings fits well with the results generated by, respectively the 2- and 3-Res conceptual model.

\section{Conclusions}

Based on the calculated performance indicators the 2- and 3-Res models perform equally well using the times series of the micro-catchments M1 and M2. In general both models are capable of predicting the runoff slightly better during model validation than

calibration. Basically the bottom reservoir represents the water release of the mineral horizon and the bedrock layer sustaining the basin discharge during dry periods. The top reservoir of the 2-Res model concept mimics the lateral subsurface flow through the highly organic epipedons. During wet conditions most of the runoff is generated by the lateral flow in the organic rich horizons. Addition of a 3rd reservoir, representing the

tion of the peak flows. To make the predictions of the runoff of the $\mathrm{M} 3$ micro-catchment acceptable using the soil-based conceptual model, the model structure should include

\section{HESSD}

9, 2475-2510, 2012

\section{Hydrologic response of tropical Andean micro-catchments in Southern Ecuador}

P. Crespo et al.

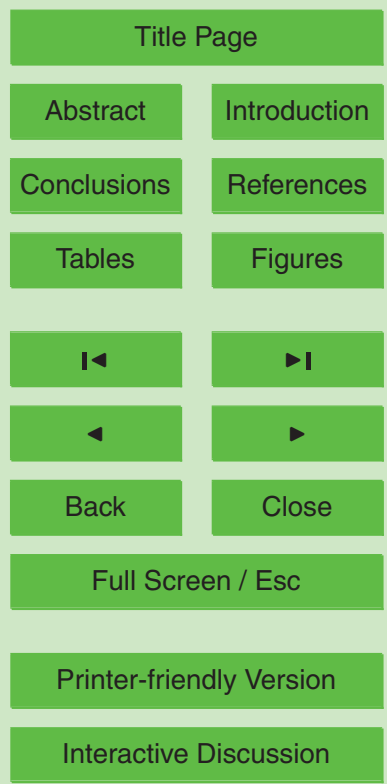


at least three reservoirs. The upper reservoir mimics the lateral flow through the $O$ and $A$, organic rich, horizons during wet periods, the 2 nd reservoir the flow through the mineral Bw horizon 40 to $50 \mathrm{~cm}$ thick, and the bottom, the $3 \mathrm{rd}$ reservoir the flow in the C-horizon, the weathered top of the bedrock and the bedrock. Baseflow dominates 5 runoff during dry spell periods. For the simulation of the runoff timeseries of the M4 micro-catchment, acceptable results are obtained applying the 2-Res model structure. However, the 3-Res model structure considerably improves the model accuracy during the model calibration and validation period. The 3rd reservoir added to the 2-Res model structure represents the contribution to the runoff by the bedrock layer, being 10 particular important during dry periods. Simulation results reveal that by adding a 3rd reservoir with high residence time improves the simulation of the low flows and peaks.

In general, the modeling exercise confirms that the soil-based concept is a valid approach for simulating the rainfall-runoff process of the four studied Andean microcatchments. With the model the flow contribution of the different soil compartments, 15 represented by either 2 or 3 linear reservoirs, can be characterized as a function of the overall wetness of the soil profile. Findings are in line with the observations mentioned by several authors having studied the hydrology of high mountain micro-catchments in the Andean cordillera. Not only the simplicity of the modeling concept is an advantage, but its relation with the soil enables in principle to apply the approach on ungauged micro-catchments analyzing in detail the profile composition. Delineating topographically medium sized basins in a series of micro-basins and routing the predicted outflow of each of the micro-catchments, using either the 2- or 3-Res modeling concept, might result in realistic estimates of the runoff of meso-scale basins.

Acknowledgements. The research was feasible thanks to a grant from the following donors: 25 IAMGOLD S.A. (Quimsacocha Project), PROTOS (a Belgian NGO), DIUC (the Research Office of the University of Cuenca, project "Estudio bio-hidrológico de un ecosistema de páramo húmedo Andino"), and DFG (German Research Foundation, Research Unit 816: Biodiversity and Sustainable Management of a Megadiverse Mountain Ecosystem in South Ecuador, subproject B3.2, BR2238/4-1). In addition, the first author, Patricio Crespo, was additionally 30 supported by the SENACYT PIC-11-715 project. The authors like to acknowledge the director

\section{HESSD}

$9,2475-2510,2012$

\section{Hydrologic response of tropical Andean micro-catchments in Southern Ecuador}

P. Crespo et al.

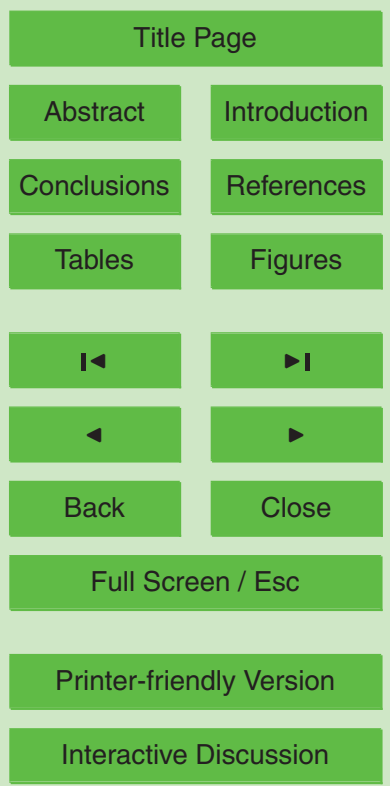


of PROMAS, Felipe Cisneros, for his support and Cristian Coello for the assistance in the collection and pre-processing of the data of the M1, M2 and M3 micro-catchments. Special thanks are due to the personnel of the San Francisco Research Station (DFG, Germany), especially to Diego Mejía for his contribution to the field sampling campaign and hydrological measurements, 5 and to Thorsten Peters and Rüttger Rollenbeck for their support in obtaining the precipitation data of the M4 micro-catchment.

\section{References}

Allen, R. G., Pereira, L. S., Raes, D., and Smith, M.: Crop evapotranspiration guidelines for computing crop water requirements, FAO Irrigation and Drainage Paper 56, FAO, Rome, 1998.

Balslev, H. and Øllgaard, B.: Mapa de vegetación del sur de Ecuador, in: Botánica Austroecuatoriana - Estudios sobre los recursos vegetales en las provincias de el Oro, edited by: Aguirre, Z. M., Madsen, J. E., Cotton, E., and Balslev, H., Loja y Zamora-Chinchipe, AbyaYala, Quito, Ecudor, 51-64, 2002.

15 Beck, E., Makeschin, F., Haubrich, F., Richter, M., Bendix, J., and Valarezo, C.: The ecosystem in the Reserva Biológica San Francisco, in: Gradients in a Tropical Mountain Ecosystem of Ecuador, edited by: Beck, E., Bendix, J., Kottke, I., Makeschin, F., and Mosandl, R., Ecological Studies, Springer Verlag, Berlin, Germany, 1-14, 2008.

Bendix, J., Rollenbeck, R., Richter, M., Fabian, P., and Emck, P.: Climate, in: Gradients in a Tropical Mountain Ecosystem of Ecuador, edited by: Beck, E., Bendix, J., Kottke, I., Makeschin, F., and Mosandl, R., Ecological Studies, Springer Verlag, Berlin, 63-74, 2008.

Beven, K. J.: Rainfall-Runoff Modeling: The Primer, Wiley and Sons, New York, USA, 2001a.

Beven, K. J.: On hypothesis testing in hydrology, Hydrol. Process., 15, 1655-1657, 2001b.

Beven, K. J. and Binley, A.: The future of distributed models: model calibration and uncertainty prediction, Hydrol. Process., 6, 279-298, 1992.

Beven, K. J. and Freer, J.: Equifinality, data assimilation and uncertainty estimation in mechanistic modelling of complex environmental systems using the glue methodology, J. Hydrol., 249, 11-29, 2001.

Blume, T., Zehe, E., and Bronstert, A.: Rainfall runoff response, event-based runoff coefficients and hydrograph separation, Hydrolog. Sci. J., 52, 843-862, 2007.
HESSD

9, 2475-2510, 2012

\section{Hydrologic response of tropical Andean \\ micro-catchments in Southern Ecuador}

P. Crespo et al.

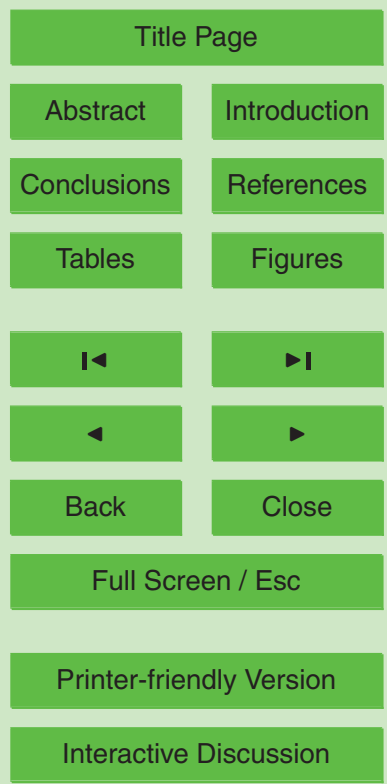


Blume, T., Zehe, E., Reusser, D. E., Iroumé, A., and Bronstert, A.: Investigation of runoff generation in a pristine, poorly gauged catchment in the Chilean Andes I: a multi-method experimental study, Hydrol. Process., 22, 3661-3675, 2008.

Bogner, C., Engelhardt, S., Zelinger, J., and Huwe, B.: Visualization and analysis of flow patterns and water flow simulations in disturbed and undisturbed tropical soils, in: Gradients in a Tropical mountain Ecosystem of Ecuador, edited by: Beck, E., Bendix, J., Kottke, I., Makeschin, F., and Mosandl, R., Ecological Studies, Springer Verlag, Berlin, 75-86, 2008.

Boy, J., Valarezo, C., and Wilcke, W.: Water flow paths in soil control element exports in an Andean tropical montane forest, Eur. J. Soil Sci., 59, 1209-1227, 2008.

10 Bruijnzeel, L. A.: Hydrology of tropical montane cloud forests: a reassessment, Land Use Water Resour. Res., 1, 1.1-1.18, 2001.

Bruijnzeel, L. A. and Veneklaas, E. J.: Climatic conditions and tropical montaine forest production: the fog has not lifted yet, Ecology, 79, 3-9, 1998.

Bücker, A., Crespo, P., Frede, H. G., Vaché, K., Cisneros, F., and Breuer, L.: Identifying controls on water chemistry of tropical cloud forest catchments - combining descriptive approaches and multivariate analysis, Aquat. Geochem., 16, 127-149, 2010.

Bücker, A., Crespo, P., Frede, H.-G., and Breuer, L.: Solute behaviour and export rates in remote neotropical mountain catchments under different land-uses, J. Trop. Ecol., 27, 305317, 2011.

20 Bussmann, R.: Bosques andinos del sur de Ecuador, clasificación, regeneración y uso, Rev. Peru. Biol., 12, 203-216, 2005.

Bussmann, R. W., Wilcke, W., and Richter, M.: Landslides as important disturbance regimes causes and regeneration, in: Gradients in a Tropical Mountain Ecosystem of Ecuador, edited by: Beck, E., Bendix, J., Kottke, I., Makeschin, F., and Mosandl, R., Ecological Studies, Springer Verlag, Berlin, 319-330, 2008.

Buytaert, W.: The properties of the soils of the south Ecuadorian páramo and the impact of land use changes on their hydrology, PhD thesis, Katholieke Universiteit Leuven, Leuven, Belgium, 228 pp., 2004.

Buytaert, W. and Beven, K.: Models as multiple working hypotheses: hydrological simulation of tropical alpine wetlands, Hydrol. Process., 25, 1784-1799, 2011.

Buytaert, W., De Bièvre, B., Wyseure, G., and Deckers, J.: The effect of land use changes on the hydrological behaviour of Histic Andosols in south Ecuador, Hydrol. Process., 19, 3985-3997, 2005.

\section{HESSD}

9, 2475-2510, 2012

\section{Hydrologic response of tropical Andean micro-catchments in Southern Ecuador}

P. Crespo et al.

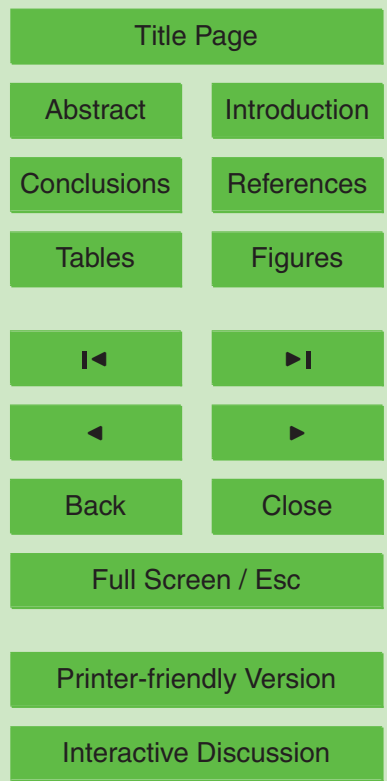


Buytaert, W., Célleri, R., Willems, P., De Bièvre, B., and Wyseure, G.: Spatial and temporal rainfall variability in mountainous areas: a case study from the south Ecuadorian Andes, J. Hydrol., 329, 413-421, 2006a.

Buytaert, W., Celleri, R., De Bièvre, B., Hofstede, R., Cisneros, F., Wyseure, G., and Deck5 ers, J.: Human impact on the hydrology of the Andean páramo, Earth-Sci. Rev., 79, 53-72, 2006b.

Buytaert, W., Iniguez, V., and De Bièvre, B.: The effects of afforestation and cultivation on water yield in the Andean páramo, Forest Ecol. Manage., 251, 22-30, 2007.

Buytaert, W., Cuesta-Camacho, F., and Tobon, C.: Potential impacts of climate change on the environmental services of humid tropical alpine regions, Global Ecol. Biogeogr., 20, 19-33, 2011.

Célleri, R.: Rainfall variability and rainfall-runoff dynamics in the Paute River basin - Southern Ecuadorian Andes, Ph. D. thesis, Katholieke Universiteit Leuven, Leuven, Belgium, 125 pp., 2007.

Célleri, R. and Feyen, J.: The hydrology of tropical Andean ecosystems: Importance, knowledge status and perspectives, Mt. Res. Dev., 29, 350-355, 2009.

Célleri, R., Willems, P., Buytaert, W., and Feyen, J.: Space-time variability of rainfall in the Paute river basin of South Ecuador, Hydrol. Process., 21, 3316-3327, 2007.

Chaves, J., Neill, C., Germer, S., Neto, S. G., Krusche, A., and Elsenbeer, H.: Land management impacts on runoff sources in small Amazon watersheds, Hydrol. Process., 22, 1766$1775,2008$.

Coltorti, M. and Ollier, C. D.: Geomorphic and tectonic evolution of the Ecuadorian Andes, Geomorphology, 32, 1-19, 2000.

Crespo, P., Coello, C., Iñiguez, V., Cisneros, F., and Ramirez, M.: Implementación de un modelo hidrológico en microcuencas del Río BuluBulu. PROTOS/SENDAS, Universidad de Cuenca, Cuenca, Ecuador, Tech. Rep., 160 pp., 2008.

Crespo, P., Célleri, R., Buytaert, W., Iñiguez, V., Borja, P., De Bievre, B., Cisneros, F., and Feyen, J.: Land use change impacts on the hydrology of Andean páramo ecosystems, in: Status and Perspectives of Hydrology in Small Basins, IAHS Publ., 336, 71-76, 2010.

so Crespo, P., Feyen, J., Buytaert, W., Bücker, A., Breuer, L., Frede, H.-G., and Ramírez, M.: Identifying controls of the hydrological response of small catchments in the tropical Andes (Ecuador), J. Hydrol., 407, 164-174, 2011 a.
HESSD

9, 2475-2510, 2012

Hydrologic response

of tropical Andean

micro-catchments in

Southern Ecuador

P. Crespo et al.

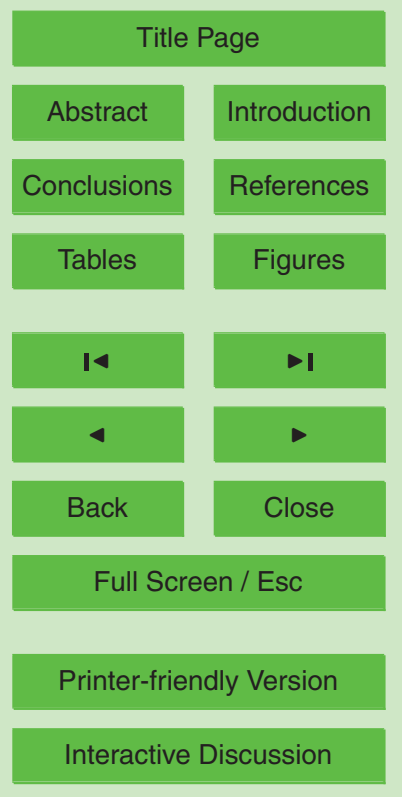


Crespo, P., Bücker, A., Feyen, J., Vaché, K., Frede, H.-G., and Breuer, L.: Preliminary evaluation of the runoff processes in a remote montane cloud forest basin using mixing model analysis and mean transit time, Hydrol. Process., doi:10.1002/hyp.8382, in press, $2011 \mathrm{~b}$.

Elsenbeer, H.: Hydraulic flowpath in tropical rainforest soil scapes: a review, Hydrol. Process., 15, 1751-1759, 2001.

Elsenbeer, H. and Lack, A.: Hydrometric and hydrochemical evidence for fast flowpaths at La Cuenca, Western Amazonia, J. Hydrol., 180, 237-250, 1996.

Elsenbeer, H., Lorieri, D., and Bonell, M.: Mixing model approaches to estimate storm flow sources in an overland flow-dominated tropical rain forest catchments, Water Resour. Res., $10 \quad 31,2267-2278,1995$.

FAO/ISRIC/ISSS: World Reference Base for Soil Resources. World Soil Resources Report 84, FAO, Rome, 88 pp., 1998.

Feddema, J. J., Oleson, K. W., Bonan, G. B., Mearns, L. O., Buja, L. E., Meehl, G. A., and Washington, W. M.: The importance of land-cover change in simulating future climates, Science, 210, 1674-1678, 2005.

Fenicia, F., McDonnell, J. J., and Savenije, H. H. G.: Learning from model improvement: on the contribution of complementary data to process understanding, Water Resour. Res., 44, W06419, doi:10.1029/2007WR006386, 2008a.

Fenicia, F., Savenije, H. H. G., Matgen, P., and Pfister, L.: Understanding catchment behavior through stepwise model concept improvement, Water Resour. Res., 44, W01402, doi:10.1029/2006WR005563, 2008b.

Fleischbein, K., Wilcke, W., Boy, J., Valarezo, C., Zech, W., and Knoblich, K.: Rainfall interception in a lower montane forest in Ecuador: effects of canopy properties, Hydrol. Process., 19, 1355-1371, 2005.

Fleischbein, K., Wilcke, W., Valarezo, C., Zech, W., and Knoblich, K.: Water budgets of three small catchments under montane forest in Ecuador: experimental and modelling approach, Hydrol. Process., 20, 2491-2507, 2006.

Goller, R., Wilcke, W., Leng, M. J., Tobschall, H. J., Wagner, K., Valarezo, C., and Zech, W.: Tracing water paths through small catchments under a tropical montane rain forest in south

30 Ecuador by an oxygen isotope approach, J. Hydrol., 308, 67-80, 2005.

Hofstede, R. G. M.: The effects of grazing and burning on soil and plant nutrient concentrations in Colombian páramo grasslands, Plant Soil, 173, 111-132, 1995.
HESSD

$9,2475-2510,2012$

\section{Hydrologic response of tropical Andean micro-catchments in Southern Ecuador}

P. Crespo et al.

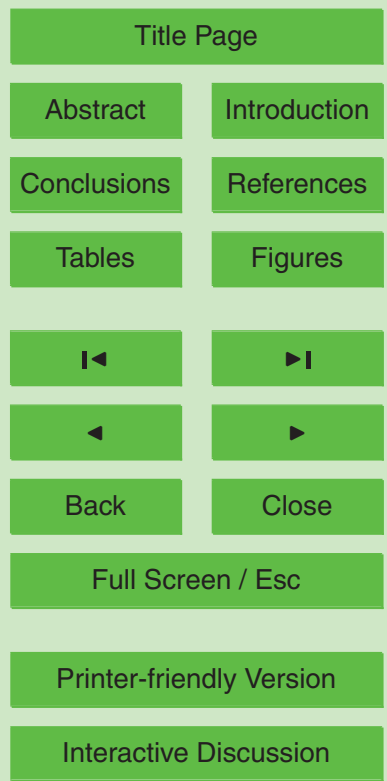


Homeier, J., Dalitz, H., and Breckle, S. W.: Waldstruktur und Baumartendiversität im momentanen Regenwald der Estación Científica San Francisco in Südecuador, Ber Reinhold-Tüxen Ges., 14, 109-118, 2002.

Hungerbühler, D.: Tertiary basins in the Andes of Southern Ecuador $\left(3^{\circ} 00^{\prime \prime}-4^{\circ} 20^{\prime \prime}\right)$ : Sedimentary evolution, deformation and regional tectonic implications, Ph. D. thesis, Institute of Geology, ETH Zürich, Switzerland, 182 pp., 1997.

Hungerbühler, D., Steinmann, M., Winkler, W., Seward, D., Eguez, A., Peterson, D. E., Helg, U., and Hammer, C.: Neogene stratigraphy and Andean geodynamics of Southern Ecuador, Earth-Sci. Rev., 57, 75-124, 2002.

10 IAMGOLD: Reporte de exploración, IAMGOLD Ecuador S. A., Cuenca, Ecuador, Tech. Rep., 120 pp., 2006.

Johnson, M., Lehmann, J., Guimarães, E., Novães, J., and Riha, S.: DOC and DIC in flowpaths of Amazonian headwater catchments with hydrologically contrasting soils, Biogeochemistry, 81, 45-57, 2006.

Klemeš, V.: Operational testing of hydrological simulation models, Hydrolog. Sci. J., 31, 13-24, 1986.

Lane, S. N., Reaney, S. M., and Heathwaite, A. L.: Representation of landscape hydrological connectivity using a topographically driven surface flow index, Water Resour. Res., 45, W08423, doi:10.1029/2008WR007336, 2009.

20

Litherland, M., Aspen, J. A., and Jemielita, R. A.: The metamorphic belts of Ecuador, Overseas Memoir British Geological Survey, 11, 1-147, 1994.

Luteyn, J. L.: Páramos: why study them?, in: Páramo: An Andean Ecosystem Under Human Influence, edited by: Balslev, H. and Luteyn, J. L., Academic Press, London, 14 pp., 1992.

Makeschin, F., Haubrich, F., Abiy, M., Burneo, J. I., and Klinger, T.: Pasture management and natural soil regeneration, in: Gradients in a Tropical Mountain Ecosystem of Ecuador, edited by: Beck, E., Bendix, J., Kottke, I., Makeschin, F., and Mosandl, R., Ecological Studies, Springer Verlag, Berlin, Germany, 431-441, 2008.

Medina, G. and Vásconez, P. M.: Los páramos en el Ecuador, edited by: Vásconez, P. M., Medina, G., and Hofstede, R., Los páramos del Ecuador, Proyecto Páramo, Quito, Ecuador, 24 pp., 2001.

Moriasi, D. N., Arnold, J. G., Van Liew, M. W., Binger, R. L., Harmel, R. D., and Veith, T. L.: Model evaluation guidelines for systematic quantification of accuracy in watershed simulations, T. ASABE, 50, 885-900, 2007.
HESSD

9, 2475-2510, 2012

Hydrologic response of tropical Andean micro-catchments in Southern Ecuador

P. Crespo et al.

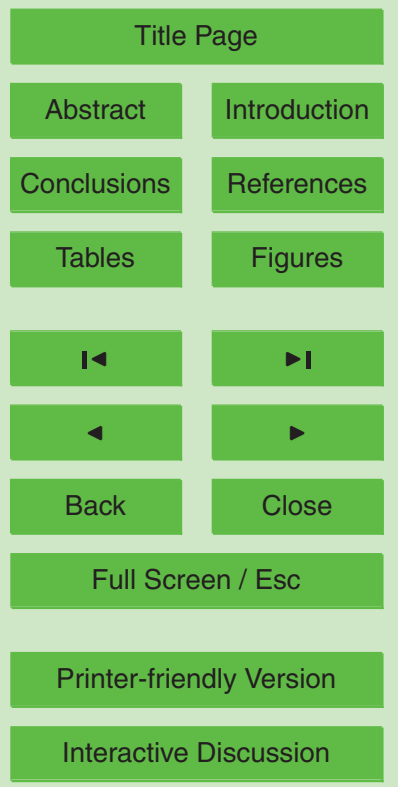


Nandakumar, N. and Mein, R. G.: Uncertainty in rainfall-runoff model simulations and the implications for predicting the hydrologic effects of land-use change, J. Hydrol., 192, 211-232, 1997.

Nash, J. E. and Sutcliffe, J. V.: River flow forecasting through conceptual models, Part I: A discussion of principles, J. Hydrol., 10, 282-90, 1970.

Plesca, I., Timbe, E., Exbrayat, J. F., Windhorst, D., Kraft, P., Crespo, P., Vaché, K., Frede, H.G., and Breuer, L.: Model intercomparison to explore catchment functioning: Results from a remote montane tropical rainforest, Ecol. Model., doi:10.1016/j.ecolmodel.2011.05.005, in press, 2011.

10 Pratt, W. T., Figueroa, J. F., and Flores, B. G.: Geology and mineralization of the area between 3 and 48 S, Western Cordillera, Ecuador, British Geological Survey, Open File Rep., WCr97r28, 1997.

Roa-García, M. C., Brown, S., Schreier, H., and Lavkulich, L. M.: The role of land use and soils in regulating water flow in small headwater catchments of the Andes, Water Resour. Res., 47, W05510, doi:10.1029/2010WR009582, 2011.

Rollenbeck, R.: Variability of precipitation in the Reserva Biólogica San Francisco/Southern Ecuador, Lyonia, 9, 43-51, 2006.

Schellekens, J., Scatena, F. N., Bruijnzeel, L. A., van Dijk, A. I. J. M., Groen, M. M. A., and van Hogezand, R. J. P.: Stormflow generation in a small rainforest catchment in the luquillo experimental forest, Puerto Rico, Hydrol. Process., 18, 505-530, 2004.

Staudinger, M., Stahl, K., Seibert, J., Clark, M. P., and Tallaksen, L. M.: Comparison of hydrological model structures based on recession and low flow simulations, Hydrol. Earth Syst. Sci., 15, 3447-3459, doi:10.5194/hess-15-3447-2011, 2011.

US Bureau of Reclamation: Water Measurement Manual, US Department of the Interior, USA, Tech. Rep., 317 pp., 2001.

Vuille, M., Bradley, R. S., and Keimig, F.: Climate variability in the Andes of Ecuador and its relation to tropical Pacific and Atlantic sea surface temperature anomalies, J. Climate, 13, 2520-2535, 2000.

Wilcke, W., Yasin, S., Abramowski, U., Valarezo, C., and Zech, W.: Nutrient storage and turnover in organic layers under tropical montane rain forest in Ecuador, Eur. J. Soil Sci., 53, 15-27, 2002.

Zimmermann, B. and Elsenbeer, $\mathrm{H}$.: The near-surface hydrological consequences of disturbance and recovery: a simulation study, J. Hydrol., 364, 115-127, 2008.

\section{HESSD}

9, 2475-2510, 2012

\section{Hydrologic response of tropical Andean micro-catchments in Southern Ecuador}

P. Crespo et al.

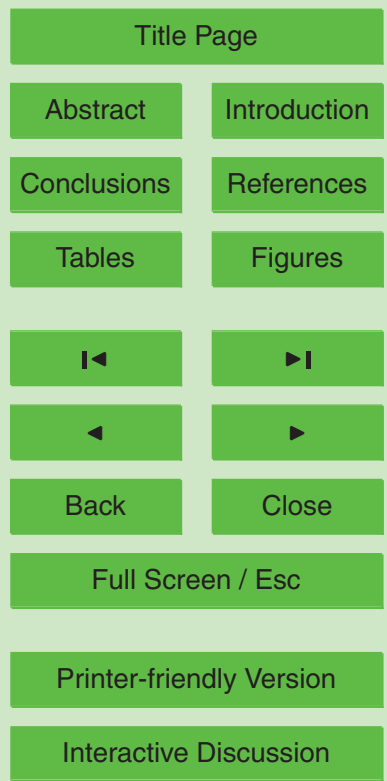




\section{HESSD}

9, 2475-2510, 2012

Table 1. Main catchment characteristics.

\begin{tabular}{|c|c|c|c|c|c|}
\hline \multirow[t]{2}{*}{ Characteristic } & \multirow[t]{2}{*}{ Unit } & \multicolumn{4}{|c|}{ Catchment } \\
\hline & & M1 Zhurucay & M2 Huagrahuma & M3 Ortigas & M4 San Ramon \\
\hline Area & $\mathrm{km}^{2}$ & 1.34 & 2.58 & 0.99 & 4.62 \\
\hline Altitude & m a.s.l & $3680-3900$ & $3690-4100$ & $2305-2880$ & $1743-3150$ \\
\hline Slope & $\%$ & 18 & 45 & 43 & 61 \\
\hline Shape & & EOR & SO & so & $\mathrm{CO}$ \\
\hline Geology & & $\begin{array}{l}\text { Quimsacocha Fm.: } \\
\text { volcanic and vol- } \\
\text { canoclastic rocks }\end{array}$ & $\begin{array}{l}\text { Saraguro Fm.: I } \\
\text { volcanoclastic de }\end{array}$ & $\begin{array}{l}\text { s and andesitic } \\
\text { its }\end{array}$ & $\begin{array}{l}\text { Chiguinda unit: } \\
\text { palaeozoic } \\
\text { metamorphic } \\
\text { rocks }\end{array}$ \\
\hline Soil distribution & $\%$ & $\begin{array}{l}\text { Andosol (85), His- } \\
\text { tosol (15) }\end{array}$ & Andosol (100) & $\begin{array}{l}\text { Andosol (74), Lep- } \\
\text { tosol (26) }\end{array}$ & $\begin{array}{l}\text { Histosol (60), Cam- } \\
\text { bisol (30), Regosol } \\
(10)\end{array}$ \\
\hline Vegetation cover & $\%$ & $\begin{array}{l}\text { Tussock grass (71), } \\
\text { shrubs (2), } \\
\text { Pasture (27) }\end{array}$ & $\begin{array}{l}\text { Tussock } \\
\text { grass (100) }\end{array}$ & $\begin{array}{l}\text { Upper montane for- } \\
\text { est }(76), \text { pasture } \\
(20), \text { cropland }(4)\end{array}$ & $\begin{array}{l}\text { Upper montane } \\
\text { cloud forest }(80) \text {, } \\
\text { sub-páramo }(18) \text {, } \\
\text { shrubs (2) }\end{array}$ \\
\hline Landuse & & Extensive grazing & Natural & $\begin{array}{l}\text { Natural, extensive } \\
\text { grazing }\end{array}$ & Natural \\
\hline $\begin{array}{l}\text { Observation period } \\
\text { length }\end{array}$ & days & $\begin{array}{l}26 \text { Oct } 2006- \\
11 \text { Nov } 2008 \\
747\end{array}$ & $\begin{array}{l}8 \text { Aug 2001- } \\
16 \text { Jun } 2005 \\
1408\end{array}$ & $\begin{array}{l}16 \text { Jan 2006- } \\
15 \text { Jul } 2008 \\
911\end{array}$ & $\begin{array}{l}23 \text { Apr 2007- } \\
25 \text { Aug } 2008 \\
490\end{array}$ \\
\hline Precipitation & $\mathrm{mm} \mathrm{yr}^{-1}$ & 1241 & 1460 & 1715 & 3796 \\
\hline Discharge & $\mathrm{mm} \mathrm{yr}^{-1}$ & 913 & 1059 & 803 & 3066 \\
\hline Runoff coefficient & & 0.74 & 0.74 & 0.46 & 0.81 \\
\hline
\end{tabular}

\section{Hydrologic response of tropical Andean micro-catchments in Southern Ecuador}

P. Crespo et al.

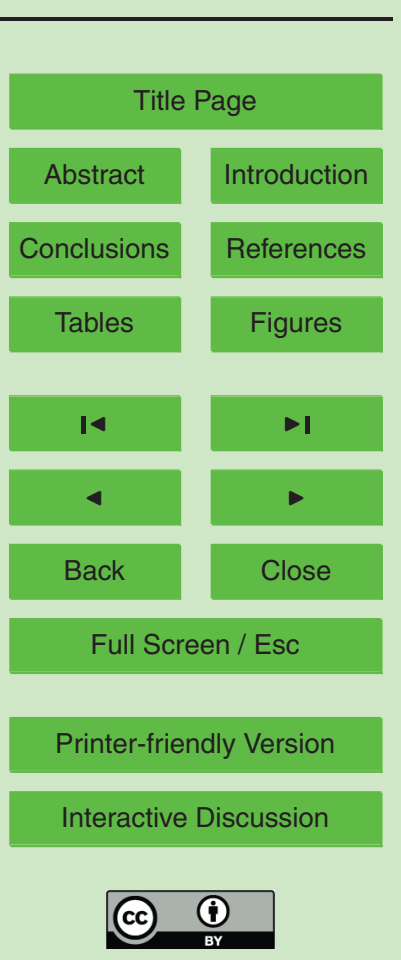




\section{HESSD}

9, 2475-2510, 2012

Table 2. Horizon properties of the main soils in the catchments.

\begin{tabular}{|c|c|c|c|c|c|c|c|c|c|c|c|}
\hline Catchment/horizon & $\begin{array}{r}\text { Depth } \\
(\mathrm{cm})\end{array}$ & $\begin{array}{l}\text { Bulk density } \\
\left(\mathrm{g} \mathrm{cm}^{-3}\right)\end{array}$ & $\mathrm{pH}$ & $\begin{array}{r}\text { SOM } \\
(\%)\end{array}$ & $\begin{array}{r}K_{\mathrm{s}} \\
\left(\mathrm{mm} \mathrm{h}^{-1}\right)\end{array}$ & $\begin{array}{l}\mathrm{pF}=0 \\
\left(\mathrm{~cm}^{3} \mathrm{~cm}^{-3}\right)\end{array}$ & $\begin{array}{l}\mathrm{pF}=2 \\
\left(\mathrm{~cm}^{3} \mathrm{~cm}^{-3}\right)\end{array}$ & $\begin{array}{l}\mathrm{pF}=4.2 \\
\left(\mathrm{~cm}^{3} \mathrm{~cm}^{-3}\right)\end{array}$ & $\begin{array}{l}\text { Sand } \\
(\%)\end{array}$ & $\begin{array}{l}\text { Silt } \\
(\%)\end{array}$ & $\begin{array}{r}\text { Clay } \\
(\%)\end{array}$ \\
\hline \multicolumn{12}{|l|}{ M1 (Zhurucay) } \\
\hline Ah & $20-40$ & $0.21-0.35$ & $4.3-4.8$ & $15-31$ & $8-12$ & $0.7-0.85$ & $0.67-0.82$ & $0.36-0.44$ & $67-80$ & $17-30$ & $12-34$ \\
\hline $\mathrm{H}$ & $22-31$ & $0.1-0.21$ & $4.4-4.7$ & $33-50$ & $5-12$ & $0.85-0.90$ & $0.84-0.90$ & $0.15-0.39$ & $56-64$ & $20-30$ & $14-26$ \\
\hline A & $16-50$ & $0.2-0.5$ & $4.5-5.7$ & $24-44$ & $5-33$ & $0.74-0.89$ & $0.72-0.86$ & $0.30-0.52$ & $34-53$ & $30-44$ & $12-38$ \\
\hline C & - & $0.76-1.11$ & $4.3-6.0$ & $0.4-4.7$ & $7.9-41$ & $0.63-0.66$ & $0.58-0.63$ & $0.18-0.40$ & $42-74$ & $24-30$ & $4-36$ \\
\hline \multicolumn{12}{|l|}{ M2 (Huagrahuma) } \\
\hline $\mathrm{Ah}$ & $18-25$ & $0.29-0.44$ & $4.6-4.8$ & $16.7-31.0$ & $9-38$ & 0.8 & -0.90 & 39 & $29-40$ & $43-49$ & $11-28$ \\
\hline A & $18-30$ & $0.25-0.37$ & $4.8-5.0$ & $17.5-31$ & $10-34$ & 0.66 & -0.83 & .74 & $26-32$ & $35-43$ & $25-41$ \\
\hline C & - & $0.75-1.3$ & $4.5-4.9$ & $0.4-8.6$ & $2-28$ & $0.71-0.79$ & $0.65-0.72$ & $0.32-0.50$ & $64-67$ & $16-23$ & $10-20$ \\
\hline \multicolumn{12}{|l|}{ M3 (Ortigas) } \\
\hline $\mathrm{O}$ & $15-30$ & $0.1-0.2$ & $5.6-6.0$ & $23-60$ & 28-105 & $0.66-0.77$ & $0.59-0.71$ & $0.18-0.58$ & $38-50$ & $43-50$ & $12-35$ \\
\hline A & $13-30$ & $0.4-0.6$ & $4.0-6.0$ & $16-29$ & $22-60$ & $0.71-0.93$ & $0.65-0.89$ & $0.48-0.49$ & $28-42$ & $45-47$ & $11-27$ \\
\hline Bw & $40-50$ & 0.3 & $5.6-6.0$ & $1-8$ & $23-60$ & $0.64-0.76$ & 0.59 .0 .76 & $0.33-0.59$ & $41-68$ & $27-37$ & $5-22$ \\
\hline C & - & $0.44-1.4$ & $5.7-6.0$ & $1-8$ & $26-60$ & $0-60-0.74$ & $0.59-0.61$ & $0.33-0.49$ & $46-68$ & $27-35$ & $9-27$ \\
\hline \multicolumn{12}{|l|}{ M4 (San Ramon) } \\
\hline 0 & $8-20$ & $0.1-0.2$ & $4.2-4.4$ & $33-44$ & $160-167$ & - & - & - & 42 & 38 & 20 \\
\hline $\mathrm{H}$ & $8-20$ & $0.1-0.3$ & 4.8 & 28 & $83-91$ & 0.76 & 0.5 & 0.23 & 37 & 42 & 21 \\
\hline Ah & $8-40$ & $0.2-1.1$ & $4.8-5.4$ & $8-28$ & $11-91$ & $0.55-0.76$ & $0.50-0.52$ & $0.23-0.26$ & $29-38$ & 42 & $20-28$ \\
\hline Bw & $15-80$ & $1.0-1.3$ & $5.1-5.7$ & $0.3-13$ & $9-23$ & $0.68-0.70$ & $0.46-0.63$ & $0.19-0.36$ & $19-30$ & $42-49$ & $21-38$ \\
\hline C & - & - & - & - & $11-18$ & 0.59 & 0.40 & 0.25 & - & - & - \\
\hline
\end{tabular}

\section{Hydrologic response of tropical Andean micro-catchments in Southern Ecuador}

P. Crespo et al.

Legend: $\mathrm{pH}$, soil acidity expressed as amount of $\mathrm{H}^{+}$cations in soil solution; SOM, soil organic matter in $\% ; K_{\mathrm{s}}$, saturated hydraulic conductivity in mm $\mathrm{h}^{-1}$; $\mathrm{pF}$, soil matric potential expressed as the $\log _{10}(\mathrm{~cm}$ water column), respectively at saturation, field capacity and wilting point and corresponding soil water conent in $\mathrm{cm}^{3} \mathrm{~cm}^{-3}$; Sand, Silt and Clay, main particle size classes in percent.

.




\section{HESSD}

9, 2475-2510, 2012

Table 3. Model performance indicators.

\begin{tabular}{|c|c|c|c|c|c|c|c|c|}
\hline \multirow{2}{*}{ Model structure } & \multicolumn{4}{|c|}{ Calibration } & \multicolumn{4}{|c|}{ Evaluation } \\
\hline & Data period & BIAS & EF & $A C$ & Data period & BIAS & $\mathrm{EF}$ & $A C$ \\
\hline \multicolumn{9}{|l|}{ M1 (Zhurucay) } \\
\hline 2-Res & 26 Oct 2006- & 0.03 & 0.66 & 68 & 27 Mar 2008- & 0.01 & 0.74 & 65 \\
\hline 3-Res & 26 Mar 2008 & 0.02 & 0.68 & 79 & 11 Nov 2008 & 0.01 & 0.75 & 77 \\
\hline \multicolumn{9}{|l|}{ M2 (Huagrahuma) } \\
\hline 2-Res & 8 Aug 2001- & 0.03 & 0.73 & 65 & 14 Aug 2003- & 0.02 & 0.71 & 62 \\
\hline $\begin{array}{l}\text { 3-Res } \\
\text { M3 (Ortigas) }\end{array}$ & 7 Feb 2003 & 0.02 & 0.74 & 73 & 16 Jun 2005 & 0.01 & 0.73 & 71 \\
\hline 2-Res & 16 Jan 2006- & 0.08 & 0.36 & NA & 17 Jan 2007- & 0.05 & 0.28 & NA \\
\hline $\begin{array}{l}\text { 3-Res } \\
\text { M4 (San Ramon) }\end{array}$ & 16 Jan 2007 & -0.04 & 0.92 & 70 & 15 Jul 2008 & 0.02 & 0.83 & 63 \\
\hline 2-Res & 23 Apr 2007- & 0.09 & 0.63 & 56 & 23 Apr 2007- & 0.01 & 0.60 & 47 \\
\hline 3-Res & 23 Apr 2008 & -0.01 & 0.71 & 69 & 23 Apr 2008 & 0.03 & 0.69 & 71 \\
\hline
\end{tabular}

\section{Hydrologic response of tropical Andean micro-catchments in Southern Ecuador}

P. Crespo et al.

Legend: EF, Nash-Sutcliffe Efficiency; AC, accuracy (\% of observations within the prediction limits); NA, not applicable, uncertainty limits could not be generated because the maximum EF is lower than the threshold selected for the GLUE analysis.

Title Page

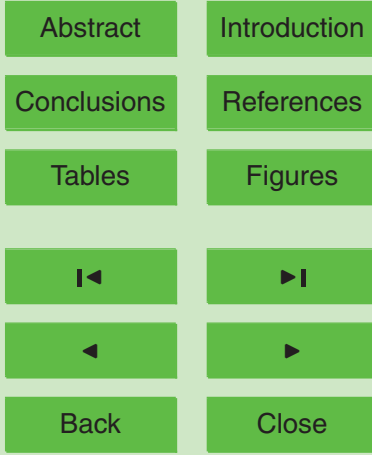

Full Screen / Esc

Printer-friendly Version

Interactive Discussion 


\section{HESSD}

9, 2475-2510, 2012

\section{Hydrologic response of tropical Andean micro-catchments in Southern Ecuador}

P. Crespo et al.

Table 4. Reservoir flow contribution (\%).

\begin{tabular}{lrrrc}
\hline Flow & M1 Zhurucay & M2 Huagrahuma & M3 Ortigas & M4 San Ramon \\
\hline Direct & 0.5 & 1.2 & 0.2 & 10.2 \\
First reservoir & 31.0 & 28.0 & 43.8 & 66.3 \\
Second reservoir & 57.3 & 60.0 & 26.0 & 10.2 \\
Third reservoir & 11.2 & 10.8 & 30.0 & 13.3 \\
\hline
\end{tabular}

Title Page

Abstract Introduction

Conclusions

References

Tables

Figures

14

4

Back

Full Screen / Esc

Printer-friendly Version

Interactive Discussion 


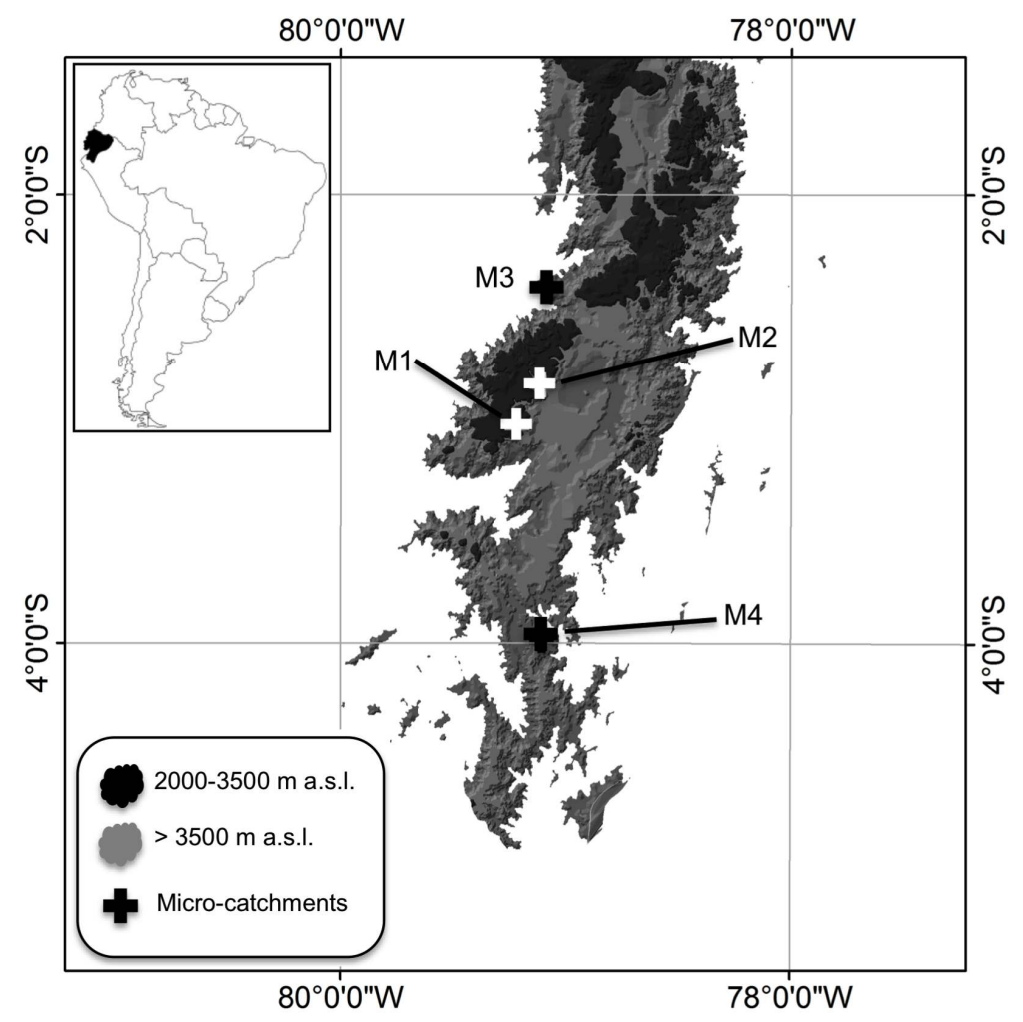

\section{HESSD}

9, 2475-2510, 2012

Hydrologic response of tropical Andean micro-catchments in Southern Ecuador

P. Crespo et al.

Title Page

Abstract

Conclusions

Tables

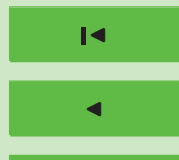

Back

Introduction

References

Figures

$>1$

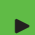

Close

Full Screen / Esc

Fig. 1. Location of the four study micro-catchments.

Printer-friendly Version

Interactive Discussion 


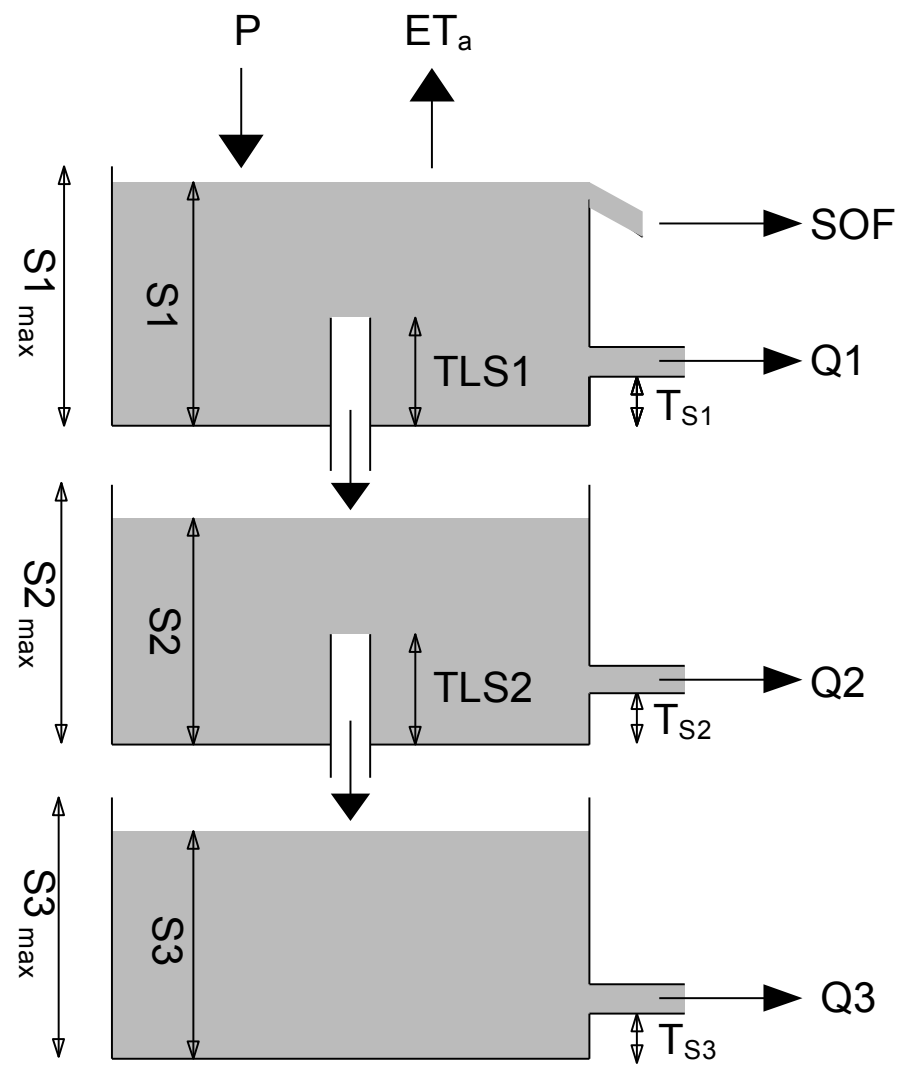

Fig. 2. Schematic presentation of the concept of the 3-Res (3-reservoir) model (based on Crespo et al., 2011a,b).

\section{HESSD}

9, 2475-2510, 2012

Hydrologic response of tropical Andean micro-catchments in Southern Ecuador

P. Crespo et al.

\section{Title Page}

\section{Abstract}

Introduction

Conclusions

References

Tables

Figures

14

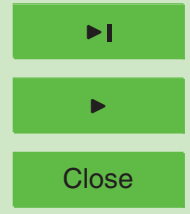

Back

Full Screen / Esc

Printer-friendly Version

Interactive Discussion 

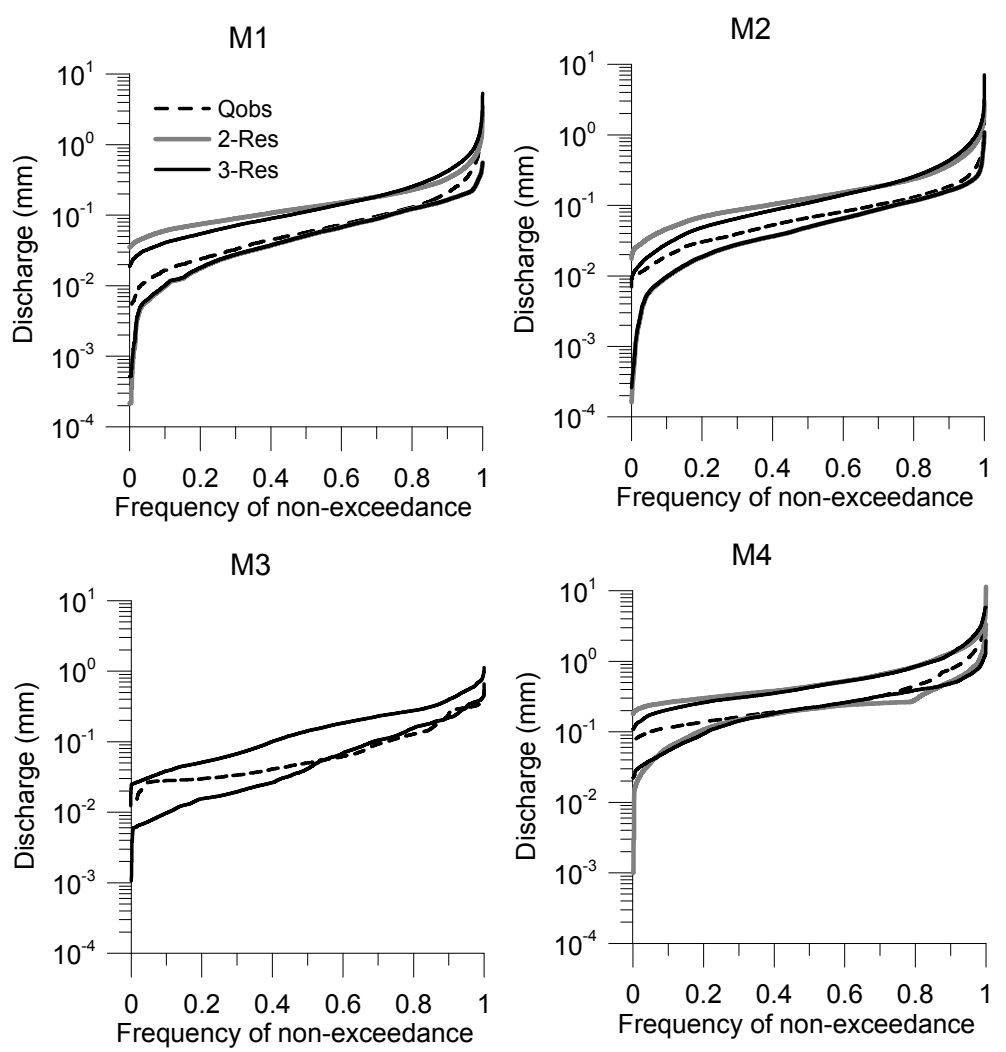

\section{HESSD}

9, 2475-2510, 2012

Hydrologic response of tropical Andean micro-catchments in Southern Ecuador

P. Crespo et al.

\section{Title Page}

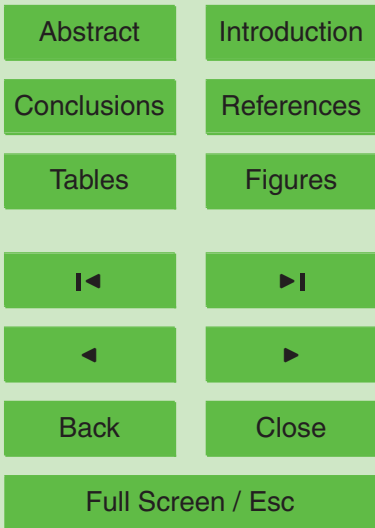

Printer-friendly Version

Fig. 3. Hourly flow duration curves for the observed discharge and the 5 and $95 \%$ uncertainty limits of the four micro-catchments applying, respectively the 2- and 3-Res model structure. 

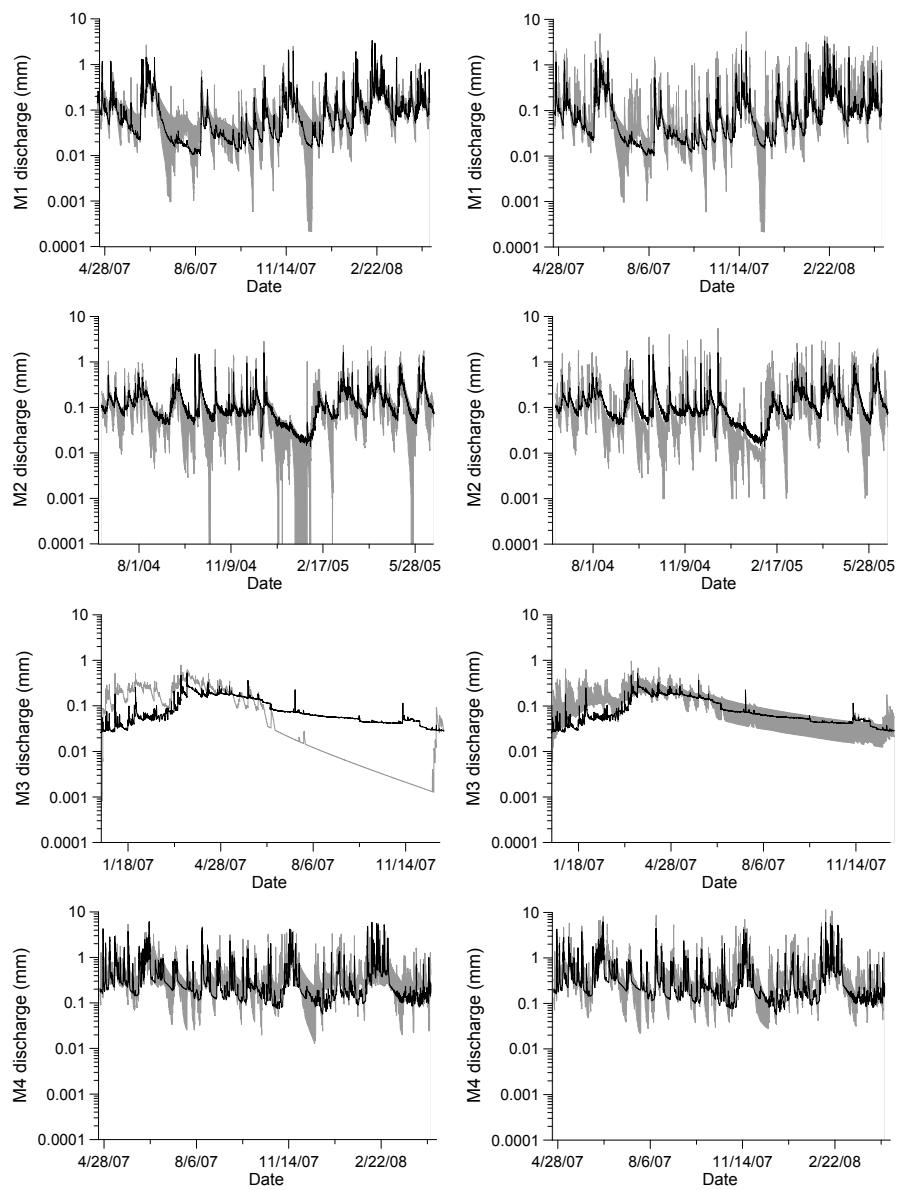

Fig. 4. Observed discharge and the 5 and $95 \%$ uncertainty limits on the predicted discharge with application to the four micro-catchments. Left figures correspond to the 2-Res model structure, while right figures to the 3-Res model structure. 2-Res model results for M3 correspond to the best model simulation.
HESSD

9, 2475-2510, 2012

\section{Hydrologic response of tropical Andean micro-catchments in Southern Ecuador}

P. Crespo et al.

Title Page

Abstract

Introduction

Conclusions

References

Tables

Figures

14

$>$ I

4

Back

Close

Full Screen / Esc

Printer-friendly Version

Interactive Discussion 

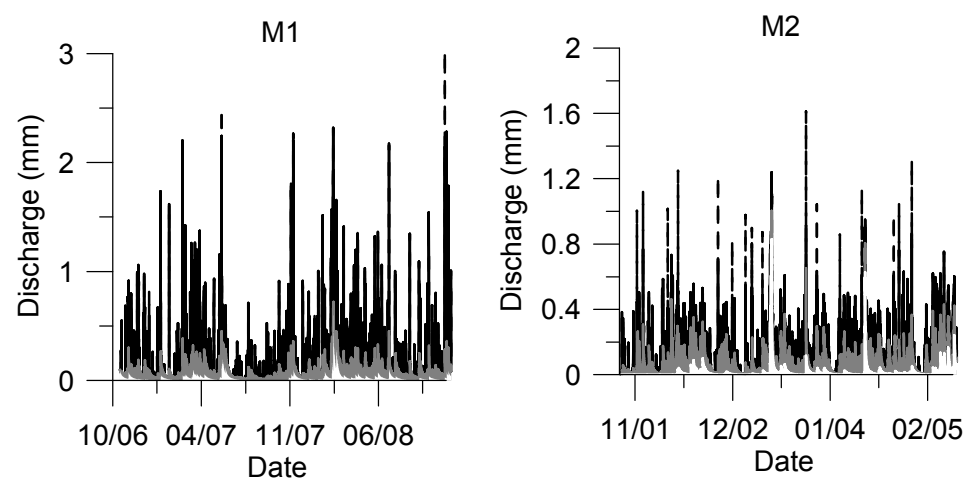

HESSD

9, 2475-2510, 2012

Hydrologic response of tropical Andean micro-catchments in Southern Ecuador

P. Crespo et al.
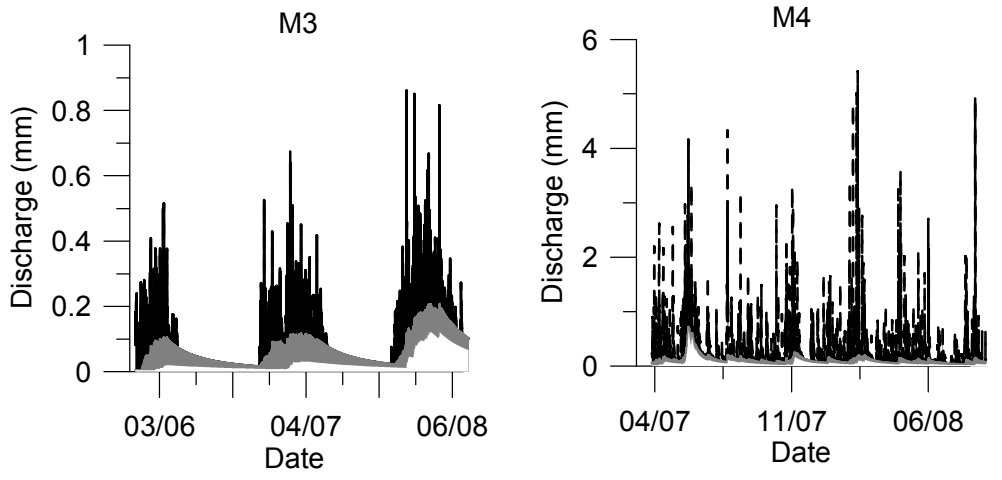

Title Page

Abstract

Introduction

Conclusions

References

Tables

Figures

14

$\rightarrow 1$

4

Back

Close

Full Screen / Esc

Fig. 5. Discharge components according to the 3-Res model structure, with application to the four micro-catchments.

Printer-friendly Version

Interactive Discussion 